\section{OPEN ACCESS}

Edited by:

Olivier Cuvillier,

Centre National de La Recherche Scientifique (CNRS), France

Reviewed by:

Renata Ciccarelli,

Università degli Studi G. d'Annunzio

Chieti e Pescara, Italy

Vito Pistoia,

Bambino Gesù Ospedale Pediatrico (IRCCS), Italy

${ }^{*}$ Correspondence: Claudiana Lameu claulameu@usp.br

Specialty section:

This article was submitted to Pharmacology of Anti-Cancer Drugs,

a section of the journal

Frontiers in Pharmacology

Received: 09 March 2018 Accepted: 26 April 2018

Published: 18 May 2018

Citation:

Ulrich H, Ratajczak MZ, Schneider G, Adinolfi E, Orioli E, Ferrazoli EG,

Glaser T, Corrêa-Velloso J,

Martins PCM, Coutinho F,

Santos APJ, Pillat MM, Sack U and

Lameu C (2018) Kinin and Purine

Signaling Contributes to

Neuroblastoma Metastasis

Front. Pharmacol. 9:500.

doi: 10.3389/fphar.2018.00500

\title{
Kinin and Purine Signaling Contributes to Neuroblastoma Metastasis
}

\begin{abstract}
Henning Ulrich ${ }^{1}$, Mariusz Z. Ratajczak ${ }^{2,3}$, Gabriela Schneider ${ }^{2}$, Elena Adinolfi ${ }^{4}$, Elisa Orioli ${ }^{4}$, Enéas G. Ferrazoli ${ }^{1}$, Talita Glaser ${ }^{1}$, Juliana Corrêa-Velloso ${ }^{1}$, Poliana C. M. Martins ${ }^{1}$, Fernanda Coutinho ${ }^{1}$, Ana P. J. Santos ${ }^{1}$, Micheli M. Pillat ${ }^{1}$, Ulrich Sack ${ }^{5}$ and Claudiana Lameu ${ }^{1 *}$
\end{abstract}

\begin{abstract}
${ }^{1}$ Departamento de Bioquímica, Instituto de Química, Universidade de São Paulo, São Paulo, Brazil, 2 James Graham Brown Cancer Center, Stem Cell Institute, University of Louisville, Louisville, KY, United States, ${ }^{3}$ Department of Regenerative Medicine, Center for Preclinical Research and Technology, Warsaw Medical University, Warsaw, Poland, ${ }^{4}$ Section of Pathology, Oncology and Experimental Biology, Department of Morphology, Surgery and Experimental Medicine, University of Ferrara, Ferrara, Italy, ${ }^{5}$ Institute of Clinical Immunology, Universitätsklinikum Leipzig, Leipzig, Germany
\end{abstract}

Bone marrow metastasis occurs in approximately 350,000 patients that annually die in the U.S. alone. In view of the importance of tumor cell migration into the bone marrow, we have here investigated effects of various concentrations of stromal cell-derived factor-1 (SDF-1), bradykinin- and ATP on bone marrow metastasis. We show for first time that bradykinin augmented chemotactic responsiveness of neuroblastoma cells to SDF-1 and ATP concentrations, encountered under physiological conditions. Bradykinin upregulated VEGF expression, increased metalloproteinase activity and induced adhesion of neuroblastoma cells. Bradykinin augmented SDF-1-induced intracellular $\mathrm{Ca}^{2+}$ mobilization as well as resensitization and expression of ATP-sensing P2X7 receptors. Bradykinin treatment resulted in higher gene expression levels of the truncated P2X7B receptor compared to those of the P2X7A full-length isoform. Bradykinin as pro-metastatic factor induced tumor proliferation that was significantly decreased by P2X7 receptor antagonists; however, the peptide did not enhance cell death nor P2X7A receptor-related pore activity, promoting neuroblastoma growth. Furthermore, immunodeficient nude/nude mice transplanted with bradykinin-pretreated neuroblastoma cells revealed significantly higher metastasis rates compared to animals injected with untreated cells. In contrast, animals receiving Brilliant Blue G, a P2X7 receptor antagonist, did not show any specific dissemination of neuroblastoma cells to the bone marrow and liver, and metastasis rates were drastically reduced. Our data suggests correlated actions of kinins and purines in neuroblastoma dissemination, providing novel avenues for clinic research in preventing metastasis.

Keywords: metastasis, bradykinin, neuroblastoma, purinergic system, bone marrow

\section{INTRODUCTION}

Neuroblastoma is the most common pediatric extracranial solid tumor and present as metastatic disease in about $50 \%$ of patients (Kucia et al., 2005a). The bone marrow (BM) is the main site of metastasis in advanced neuroblastoma, and detection of minimal residual neuroblastoma cells at this site correlates with poor prognosis (Seeger et al., 2000). The identification of new therapeutic 
targets causing neuroblastoma metastatic dissemination is of particular interest for advanced stage neuroblastoma patients, which despite aggressive treatment still show overall survival rate less than $40 \%$. Although chemo- and radiotherapy are the most important and effective therapeutic modalities used in cancer treatment, these are associated with undesired expression and release of several pro-metastatic factors, such as molecules related to inflammatory processes creating a favorable microenvironment for seeding of tumor cells that have survived treatment (Ratajczak et al., 2013).

The C-X-C chemokine receptor type 4 (CXCR4) and its ligand, $\alpha$-chemokine stromal-derived factor-1 (SDF-1), secreted by BM stroma supposedly participate in establishment of BM metastasis by neuroblastoma cells (Geminder et al., 2001). However, SDF-1 dose-dependent migration of neuroblastoma was observed only when CXCR4 expression and activity had been upregulated. Thus, we here propose the existence of other mechanisms regulating neuroblastoma trafficking to the $\mathrm{BM}$ and/or increasing responsiveness of neuroblastoma to SDF-1 by sensitization or overexpression of the CXCR4.

For this, we have studied interactions of factors originated by inflammatory processes and/or leakage of damaged cells, such as adenosine triphosphate (ATP) and bradykinin (BK) (Pinheiro et al., 2013), regarding their priming effects on responsiveness to low concentration of SDF-1 and motility and invasiveness properties of neuroblastoma cells for metastasis formation.

$\mathrm{BK}$, produced by the kallikrein-kinin system, is implicated in many pathophysiological processes including tumor proliferation, migration, angiogenesis, and increased vascular permeability (da Costa et al., 2014), and, therefore, probably contributing to the metastatic behavior of neuroblastoma tumors. Extracellular ATP participates in important steps of metastasis, including rearrangement of cytoskeleton, invasion, migration and adhesion (Schneider et al., 2015). Extracellular ATP activates plasma membrane purinergic P2 receptors, subdivided into P2X ligand-gated ion channels, formed as homo- or hetero-trimeric receptors by assembly of P2X1-P2X7 subunits, and P2Y G protein-coupled receptors (P2Y1, P2Y2, P2Y4, P2Y6, P2Y11, P2Y12, and P2Y14) (Burnstock, 2007).

Among other $\mathrm{P} 2$ receptors, the $\mathrm{P} 2 \mathrm{X} 7$ subtype recently attracted increasing attention regarding its role in carcinogenesis (Adinolfi et al., 2015; Di Virgilio et al., 2016). This receptor covers a dual role in tumor cells exerting a tonic proliferative activity at low concentrations of agonist and behaving as pro-apoptotic receptor at milimolar concentrations of ATP (Adinolfi et al., 2005). Of interest, the known functional splice variants of the $\mathrm{P} 2 \mathrm{X} 7$ receptor, i.e., $\mathrm{P} 2 \mathrm{X} 7 \mathrm{~A}$ and $\mathrm{B}$ isoforms, have been associated with proliferation and cancer progression or cytotoxicity (Adinolfi et al., 2010; Giuliani et al., 2014).

We have focused on biological responses to stimulation of exogenously administered BK on neuroblastoma cell lines, such as chemotaxis in response to SDF-1 and ATP, expression and sensitization of CXCR4 and purinergic receptors, ATP-induced pore formation, cell proliferation, adhesion, MMPs activities, VEGF expression and cytoskeleton rearrangement in vitro, as well as induction of neuroblastoma cell dissemination in vivo. Altogether, our findings provide proof for interactions of BK with the purinergic signaling system and also with the CXCR4-SDF1 axis involved in metastasis, making them attractive targets for development of anti-cancer drugs.

\section{MATERIALS AND METHODS}

\section{Radiation of Mice and Isolation of Bone Marrow Cells}

Animal experimentation and sacrifice followed a protocol approved by the Ethics' committee of the University of Louisville and regulations established by the NIH. Expression patterns of kininogens 1 and 2 and BK levels in the BM were obtained after $24 \mathrm{~h}$ of exposing mice C57BL/6 to a lethal dose of $\gamma$-irradiation (1,000 cGy) by real-time PCR using the primer sequences listed in Table 1 and an ELISA kit, respectively. BM cell lysates were obtained by flushing the BM of tibia and femur cavities, and resuspending the cells of each $\mathrm{BM}$ in $3 \mathrm{ml}$ of RPMI medium, then incubated for $1 \mathrm{~h}$ at $37^{\circ} \mathrm{C}$ and centrifuged $\left(680 \times \mathrm{g}, 10 \mathrm{~min}, 4^{\circ} \mathrm{C}\right)$. Red blood cells from the BM were then lysed using "Lysis Buffer" (Becton \& Dickinson, San Jose, CA) and the white blood cells pellet were stored at $-80^{\circ} \mathrm{C}$ for later use in the quantification protocol.

\section{Quantification of BK by ELISA}

BK levels of BM cell lysates of six irradiated C57/BL6 mice and six non-irradiated mice (control) were measured using the Bradykinin (Human, Rat, Mouse) ELISA Kit (Phoenix Pharmaceuticals, Inc., Burlingame, CA), according to the manufacturer's instructions. Briefly, $50 \mu \mathrm{L}$ of standard solutions or test samples were added to immunoplate multiwells, then 25 $\mu \mathrm{L}$ of each primary antisera and biotinylated peptide solution were added, and the plates were incubated for $2 \mathrm{~h}$ at room temperature with mild agitation. The plates were washed 5 times, and $100 \mu \mathrm{L}$ of diluted streptavidin-conjugated horse radish peroxidase solution was added to each well. After $60 \mathrm{~min}$ incubation at room temperature, immunoplates were washed 5 times, and $100 \mu \mathrm{L}$ of $3,3^{\prime}, 5,5^{\prime}$-tetramethyl benzidine.diHCl (TMB) solution was added to each well. After further $20 \mathrm{~min}$ incubation at room temperature, the reaction was stopped with $100 \mu \mathrm{L}$ of $2 \mathrm{~N} \mathrm{HCl}$. The absorbance was measured at $450 \mathrm{~nm}$ using the FlexStation III microplate reader (Molecular Devices, Sunnyvale, CA). TMB solution and $2 \mathrm{~N} \mathrm{HCl}(1: 1)$ were used as a blank control.

\section{Cell Lines}

Cells were cultured in appropriate media at $37^{\circ} \mathrm{C}$ in $5 \% \mathrm{CO}_{2}$ atmosphere. The medium was changed every 2 days. CHP-100 and CHP 134 human neuroblastoma cell lines were maintained in RPMI-1640, while IMR-32 and SH-SY5Y cell lines were kept in Minimum Essential Medium and Dulbecco's Modified Eagle's Medium, respectively, all of them containing $10 \%$ FBS, $100 \mathrm{U} / \mathrm{mL}$ penicillin and $10 \mu \mathrm{g} / \mathrm{mL}$ streptomycin. Both, CHP-100 (ECACC; 06122001) and SH-5YSY (CRL-2266) lines, are neuroblastoma cells isolated from metastatic site: bone marrow. The CHP-134 cell line (ECACC; 06122002) was obtained from the primary 
TABLE 1 | Primer sequences.

\begin{tabular}{|c|c|c|c|}
\hline Gene & Forward primer $\left(5^{\prime}-3^{\prime}\right)$ & Reverse primer $\left(5^{\prime}-3^{\prime}\right)$ & Species \\
\hline$P 2 X 1$ & TTGTGGAGAACGGGACCAA & GTCAAAGCGAATCCCAAACAC & Homo sapiens \\
\hline P2X2 & GATCCGCATTGACGTCATTG & TGGTGGGAATCAGGCTGAAC & Homo sapiens \\
\hline P2X3 & GCATCCCCAAATACTCCTTCAC & GGACACGCTGCTITCTCAGA & Homo sapiens \\
\hline P2X4 & GCCGCCTCGATACACGGGAC & TGCTCGTTGCCAGCCAGGTC & Homo sapiens \\
\hline P2X5 & CCTTCCTGCCAGCTGTITG & TGCCATCTCCCCCACTITAA & Homo sapiens \\
\hline P2X6 & CCAAACAACACCACCGAGATC & TGGGACCAAGAGGAGAATTCC & Homo sapiens \\
\hline P2X7 & ACTGCAACCTAGACCGTTGGTT & TCAAGGCGACGGAAACTGTAT & Homo sapiens \\
\hline P2X7A & CGGCTCAACCCTCTCCTACT & GGAGTAAGTGTCGATGAGGAAGTC & Homo sapiens \\
\hline P2X7B & GGAAAATGGTTGGAGAAGGAAGTG & CGATGAGGAAGTCGATGAACACA & Homo sapiens \\
\hline P2Y1 & GGATGCCATGTGTAAACTGC & GTACACCACACCGCTGTACC & Homo sapiens \\
\hline P2Y2 & CACCCGCACCCTCTACTACT & CCTTGTAGGCCATGTTGATG & Homo sapiens \\
\hline P2Y4 & CCGTCCTGTGCCATGACA & GCTGAAGTGCACATAGTGGTCAA & Homo sapiens \\
\hline P2Y6 & GCCGGCGACCACATGA & CCTGCCTCTGCCATTTGG & Homo sapiens \\
\hline P2Y11 & CATGGCAGCCAACGTCTCGG & GGGCCACAGGAAGTCCCCCT & Homo sapiens \\
\hline P2Y12 & AATGCAAGCCGTCGACAAC & CTCTGGTGCACAGACTGGTGTT & Homo sapiens \\
\hline P2Y13 & GTGCCACGAGCTCCAACAC & TGAGGCCATGGAAGAAAACG & Homo sapiens \\
\hline P2Y14 & TCTTCATTGCAGGAATCCTACTCA & AGAGCTGGGCACGTAAAAGAAT & Homo sapiens \\
\hline Kininogen 1 & AGGGCAACTGCTCTGCTCAG & TGAAGTCACAGTCCTGCCATG & Mus musculus \\
\hline Kininogen 2 & AGGCTGTGGATGCCTCTCTG & TGCCGCTITGTAACCTAGCA & Mus musculus \\
\hline$\beta 2$-microglobulin & AATGCGGCATCTTCAAACCT & TGACTITGTCACAGCCCAAGATA & Homo sapiens \\
\hline GAPDH & CCTCCCGCTTCGCTCTCT & GCTGGCGACGCAAAAGA & Homo sapiens \\
\hline GAPDH & TGCACCACCAACTGCTTAG & GGATGCAGGGATGATGTTC & Mus musculus \\
\hline VEGF & CACCCATGGCAGAAGGAGGA & GGTCTCGATTGGATGGCAGTAG & Homo sapiens \\
\hline MMP2 & TCAAGGGCATTCAGGAGCTC & TGCCAAGGTCAATGTCAGGAG & Homo sapiens \\
\hline MMP9 & TGGTTACACTCGGGTGGCA & GGCCCCAGAGATITCGACTC & Homo sapiens \\
\hline$\alpha$-satellite & ACCACTCTGTGTCCTTCGTTCG & ACTGCGCTCTCAAAAGGAGTGT & Homo sapiens \\
\hline$\beta$-actin & TTCAАТTCСAАСАСТGTССТGTCT & CTGTGGAGTGACTAAATGGAAACC & Mus musculus \\
\hline
\end{tabular}

neuroblastoma tumor mass of the adrenal gland, and IMR32 cells (CCL-127) were derived from metastatic sites in the abdominal mass.

\section{Adhesion Assay}

Neuroblastoma cells were maintained in a quiescent state for $24 \mathrm{~h}$ in medium supplemented with $0.2 \%$ BSA in the absence or presence of $\mathrm{BK}(10,30$, or $1,000 \mathrm{nM})$. Cells $\left(5 \times 10^{4} /\right.$ well $)$ were directly added to wells pretreated with $10 \mu \mathrm{g} / \mathrm{mL}$ fibronectin at $4^{\circ} \mathrm{C}$ overnight and blocked with $0.5 \%$ BSA for $2 \mathrm{~h}$ before the experiment. After $8 \mathrm{~min}$ incubation at $37^{\circ} \mathrm{C}$, 96-well plates were vigorously washed three-times to remove nonadherent cells. Adherent cells were counted using an inverted microscope.

\section{Immunofluorescence Assay}

Immunocytochemistry assays were performed according to Lameu et al. (2012). Briefly, the CHP-100 cells were fixed with $4 \%$ para-formaldehyde (PFA), permeabilized and blocked during $1 \mathrm{~h}$ with $3 \%$ BSA and $0.25 \%$ (v/v) Triton X-100 in PBS, followed by an overnight incubation with the anti-Vascular Endothelial Growth Factor primary antibody (V6627, Anti-VEGF, SigmaAldrich) at final concentration of $10 \mu \mathrm{g} / \mathrm{mL}$. After that, cells were washed with PBS, and secondary anti-Goat Cy3 (C2821, Sigma) at 1:100 dilution were added and incubated for $3 \mathrm{~h}$. Sequentially, washing with PBS $1 \mathrm{x}$ and DAPI (CALBIOChem; $1 \mu \mathrm{g} / \mathrm{mL}$ ) was used as a nuclear stain. Slides were mounted and analyzed under a fluorescence microscope (Axiovert 200, Zeiss, Jena, Germany) and analyzed with Image J (Wayne Rasband, NIH, Bethesda, $\mathrm{MD})$.

\section{Gelatin Zymography}

To evaluate MMP-2 and MMP-9 activities, CHP-100 cells were incubated for $24 \mathrm{~h}$ in serum-free medium in the absence or presence of $10 \mathrm{nM} \mathrm{BK}$, and zymography was carried out as described previously (Jankowski et al., 2003) using $200 \mu \mathrm{g}$ total protein of cell lysate obtained with EDTA-free RIPA. Quantitative assessment of active form MMP-2 band intensity was done by densitometry using program Image J software (Wayne Rasband, $\mathrm{NIH}$, Bethesda, MD).

\section{Analysis of Rearrangements of Actin Cytoskeleton}

To visualize the actin cytoskeleton, CHP-100 cells were cultured in RPMI 1640 with 10\% FBS on slides with chambers until appropriate attachment. Then, the medium was changed and the cells were maintained in serum-free media in the absence or presence $10 \mathrm{nM}$ BK for $24 \mathrm{~h}$. Subsequently, the cells were fixed 
for $30 \mathrm{~min}$ in $4 \%$ paraformaldehyde/PBS and then stained for $1 \mathrm{~h}$ with Alexa Fluor 488 Phalloidin (Cell Signaling, Danvers, $\mathrm{MA}$ ) at a concentration of $330 \mathrm{nM}$. Images were obtained with a fluorescence microscope (Axiovert 200, Zeiss, Jena, Germany) and analyzed with the StrataQuest software (TissueGnostics $\mathrm{GmbH}$, Vienna, Austria). Briefly, the StrataQuest software is part of the TissueFAXS ${ }^{\mathrm{TM}}$ Cytometry platform-a means of image cytometry of tissue sections, tissue- and cell-cultures with a workflow and data display similar to flow cytometry. The software provides cellular data in dot-plots to show multiple measurement parameters of single cells, multicellular structures and/or morphological features.

\section{Chemotaxis Assay}

Polycarbonate membranes with $8 \mu \mathrm{m}$ pores were treated with $50 \mu \mathrm{l}$ of $0.5 \%$ gelatin. Cells were trypsinized, washed and resuspended in medium without serum containing $0.2 \%$ BSA and seeded into the upper chamber of a transwell insert (Costar Transwell, Costar Corning, Corning NY) at a density of $3 \times 10^{4}$ at $120 \mu \mathrm{l}$. The incubation period of drugs for primed cells was $3 \mathrm{~h}$ for ATP and $24 \mathrm{~h}$ for BK. The bottom part was filled with the potential chemotactic agents or $0.2 \%$ BSA (control). After $24 \mathrm{~h}$, the inserts were removed from the transwell. In case of the involvement of gene expression, a period of $24 \mathrm{~h}$ should be enough for observing effects on chemotaxis. The cells remaining in the upper chamber were removed with a cotton swab, while those that transmigrated were stained with HEMA 3 (Fisher Scientific) and counted using an inverted microscope.

\section{Flow Cytometry Analysis}

The expression of CXCR4 by neuroblastoma cell lines was detected with an Allophycocyanin (APC)-anti-CXCR4 monoclonal antibody (Becton \& Dickinson), clone no. 12.G5. Briefly, the cells were stained in phosphate-buffered saline (PBS; $\mathrm{Ca}$ - and $\mathrm{Mg}$-free) supplemented with $2 \%$ bovine calf serum (BCS; Hyclone, Logan, UT). After the final wash, cells were resuspended in PBS and analyzed by flow cytometry using the LSRII (Becton Dickinson, San Jose, CA).

\section{Real Time Polymerase Chain Reaction (qPCR)}

Gene expression levels were determined by real-time PCR, as previously described (Lameu et al., 2012). From the total RNA extracted of neuroblastoma cells, cDNA strands were synthetized using the cDNA Cycle Kit (Thermofisher), following manufacturer's recommendations. Real time PCR was performed in $25 \mu \mathrm{l}$ of buffer reaction containing $1 \mu \mathrm{l}$ of cDNA, SYBR Green Master Mix (Thermofisher), and 5 pmol of each sequencespecific primer (Table 1). Thermal cycling carried out with the ABI Step One Plus instrument (Thermofisher) consisted of a pre-incubation step for $2 \mathrm{~min}$ at $50^{\circ} \mathrm{C}$, then denaturation for $10 \mathrm{~min}$ at $95^{\circ} \mathrm{C}$ followed by 40 cycles for denaturation for $15 \mathrm{~s}$ at $95^{\circ} \mathrm{C}$, and annealing/extension for $1 \mathrm{~min}$ at $60^{\circ} \mathrm{C}$. Gene expression levels of GAPDH (glyceraldehyde-3-phosphate dehydrogenase) were used for normalization of gene expression. Relative gene expression of $\mathrm{P} 2 \mathrm{X} 7 \mathrm{~A}$ and $\mathrm{P} 2 \mathrm{X} 7 \mathrm{~B}$ receptor isoforms were determined with the TaqMan assay as previously described
(Adinolfi et al., 2010). Gene expression levels were normalized by using $\beta 2$-microglobulin as endogenous control (for primer sequences see Table 1). The results were analyzed for relative quantitation among groups using the comparative $2^{-\Delta \Delta C T}$ method (Livak and Schmittgen, 2001).

\section{Calcium Imaging in Single Cells}

Forty-eight hours before calcium measurements, $2.5 \times 10^{5}$ cells were seeded and allowed to attach on p35-mm culture dishes (Nalge Nunc International, Rochester, NY). Cells were loaded for $30 \mathrm{~min}$ at $37^{\circ} \mathrm{C}$ with $5 \mu \mathrm{M}$ Fluo-3AM (Sigma Chemical, St. Louis, $\mathrm{MO}$ ) in the presence of $0.5 \% \mathrm{Me}_{2} \mathrm{SO}$ and $0.1 \%$ of the nonionic surfactant pluronic acid F-127, followed by three washes with DMEM containing 10\% FBS. Fluo-3 fluorescence was excited with a xenon lamp at $488 \mathrm{~nm}$, and the emitted light was detected using a bandpass filter at $515-530 \mathrm{~nm}$. Measurements of transient changes in free intracellular $\mathrm{Ca}^{2+}$ concentration $\left[\mathrm{Ca}^{2+}\right]_{i}$ in neuroblastoma cells were evaluated by calcium imaging with an inverted Microscope (ECLIPSE-TiS, Nikon, Melville, NY), equipped with a 14 bit high-resolution CCD camera (CoolSNAP HQ2, Photometrics, Tucson, AZ). Changes in $\left[\mathrm{Ca}^{2+}\right]_{i}$ were monitored in cells pretreated for $24 \mathrm{~h}$ with $10 \mathrm{nM}$ BK and then stimulated by SDF-1 (3 or $30 \mathrm{ng} / \mathrm{mL}$ ) or Bz-ATP $(100 \mu \mathrm{M})$ compared to control experiments without BK pretreatment. The ionophore 4-Br-A23187 $(5 \mu \mathrm{M})$ and the chelating compound EGTA $(10 \mathrm{mM})$ were used to determine maximal (Fmax) and minimal (Fmin) fluorescence values, respectively. $\left[\mathrm{Ca}^{2+}\right]_{i}$ values were calculated from relative fluorescence values using the equation $\left[\mathrm{Ca}^{2+}\right]_{i}=\mathrm{K}_{\mathrm{d}}(\mathrm{F}-\mathrm{Fmin}) /(\mathrm{Fmax}-\mathrm{F})$, assuming a $\mathrm{K}_{\mathrm{d}}$ of $450 \mathrm{nM}$ for fluo-3 calcium binding (Lameu et al., 2010). Calculated concentrations are mean values of data from at least 30 individual-analyzed cells.

\section{Calcium Measurements by Microfluorimetry}

Changes in $\left[\mathrm{Ca}^{2+}\right]_{i}$ of neuroblastoma cell populations were determined by microfluorimetry using the FlexStation III (Molecular Devices Corp.). Cells were incubated for $60 \mathrm{~min}$ at $37^{\circ} \mathrm{C}$ with the FlexStation Calcium Assay Kit (Molecular Devices Corp.) containing $2.5 \mathrm{mM}$ probenecid in a final volume of $200 \mathrm{ml}$ per well. Fluorescence of samples was excited at $485 \mathrm{~nm}$, and fluorescence emission was detected at $525 \mathrm{~nm}$ (Lameu et al., 2010).

\section{Pore Formation}

In order to analyze the effects of chronical exposure to $\mathrm{BK}$ on $\mathrm{P} 2 \mathrm{X} 7$ receptor-induced pore formation, $5 \times 10^{5}$ cells were pretreated for $24 \mathrm{~h}$ with the peptide at $10 \mathrm{nM}$ concentration. Afterwards, cells were incubated for 2-3 min with Bz-ATP $(100 \mu \mathrm{M})$ and ethidium bromide $(20 \mu \mathrm{M})$. The plasma membrane permeability to ethidium bromide was analyzed by flow cytometry using the Attune flow cytometer (Thermofisher). Ethidium bromide emission fluorescence was recorded using a blue laser (488 nm) and an emission BP filter 574/26 nm (BL2 channel). The results were analyzed using the FlowJo v10.1r5 software (Ashland, OR, USA). Cells that had not been pretreated with BK were used as control. 


\section{Cell Viability Assay}

Cells were seeded in 96 well plates $\left(10^{4}\right.$ cells/well $)$ at $37^{\circ} \mathrm{C}$ in $5 \% \mathrm{CO}_{2}$. After $24 \mathrm{~h}$ of culture, cells were kept for another $24 \mathrm{~h}$ in medium supplemented with $0.2 \%$ BSA in the absence or presence of BK $(10 \mathrm{nM})$, ATP $(1 \mu \mathrm{M})$ and Bz-ATP $(100 \mu \mathrm{M})$ or combination of BK plus ATP or Bz-ATP. $10 \mu \mathrm{L}$ of MTT [(3-(4,5-Dimethylthiazol-2-yl)-2,5-diphenyltetrazolium bromide)] $(10 \mathrm{mg} / \mathrm{mL})$ was added to each well and incubated at $37^{\circ} \mathrm{C}$ for $4 \mathrm{~h}$. The medium was removed and $100 \mu \mathrm{L}$ DMSO was added and incubated for $1 \mathrm{~h}$ at room temperature. The absorbance was measured at $600 \mathrm{~nm}$ using FlexStation III (Molecular Devices Corp.). All experiments were performed in triplicates with three different passage numbers of the cell.

\section{Cell Proliferation}

Cells were plated in culture flasks at an initial density of $10^{4}$ cells $/ \mathrm{cm}^{2}$ in presence or absence of BK $(10,30$, or $1,000 \mathrm{nM})$. Cells were counted after 24,48 , and $72 \mathrm{~h}$ by flow cytometry (LSRII flow cytometer, Becton \& Dickinson).

\section{Transplantation of Human Neuroblastoma Cells Into Nude/Nude Mice and Short-Term Dissemination Assay}

To evaluate the in vivo behavior metastatic of neuroblastoma to the $\mathrm{BM}$, lung and liver was injected $2 \times 10^{6}$ cells into the tail vein of nude/nude control mice or mice i.p. injected with 50 $\mathrm{mg} / \mathrm{kg}$ Brilliant Blue G (BBG), a P2X7 receptor antagonist (Ryu et al., 2011). The dissemination assays protocols were previously approved by the Ethics' committee of the University of São Paulo (CEUA 13/2017). Animals were sacrificed $48 \mathrm{~h}$ after injection of neuroblastoma cells, and tumor cells levels in bone marrow, lungs and liver were assessed. Relative quantities of human cells present in the murine organs were determined by real-time PCR assessment of human $\alpha$-satellite DNA from these tissues as measure of the degree of chimerism, as described elsewhere (Jankowski et al., 2003). Primer sequences are listed in Table 1.

\section{Tumor Generation and Long-Term Dissemination Assay}

For tumor induction, $2 \times 10^{6} \mathrm{CHP}-100$ cells pretreated for $24 \mathrm{~h}$ with $10 \mathrm{nM}$ BK were inoculated into subcutaneous fat of the right limb. Animals were treated i.p. with $50 \mathrm{mg} / \mathrm{kg}$ BBG every 2 days, while the control group received $0.9 \%$ sterile saline solution. At the time of injection, mice were examined to assess general health conditions and to evaluate tumor growth. The major tumor mass diameter was measured with a manual caliper. On day 28 after inoculum, mice were sacrificed, tumor weight was measured, and relative human neuroblastoma cell levels in murine bone marrow were determined by qPCR as described above.

\section{RESULTS}

\section{Presence of the BK Precursors in Irradiated Bone Marrow}

For providing proof for our hypothesis that radiotherapy provides a pro-metastatic microenvironment in BM, involving
BK release, for seeding of tumor cells that survived treatment, alterations of kininogen expression and BK levels were determined in the irradiated BM.

BK precursor (kininogens-1 and 2) mRNA transcription levels were detected by qPCR in much higher concentrations in BM cells of $\gamma$-irradiated mice when compared to non-irradiated animals (Figure 1A). Furthermore, BK levels were significantly augmented in BM of irradiated animals compared to control animals, as determined by ELISA (Figure 1B). Consequently, $\mathrm{BK}$ released by damaged $\mathrm{BM}$ contributes to a favorable microenvironment for metastasis formation. Based on that, we postulate that $\mathrm{BK}$, secreted by the BM, enhances adhesion, invasion, angiogenesis and sensitizes CXCR4 to promote metastasis of neuroblastoma cells to the BM (Figure 1C).

\section{Bradykinin Induces Neuroblastoma Cells to Transform Into Pro-metastatic Phenotypes}

BK-mediated priming effects on the promotion of pro-metastatic features of tumor cells. Further, BK induced an increase of adhesion at a $10 \mathrm{nM}$ dose of the peptide for CHP-100 (Figure 2A) and IMR-32 cells (Figure 2B), and at a $30 \mathrm{nM}$ dose for CHP-134 cells (Figure 2C), respectively. The used BK concentrations had been effective in chemoattraction assays.

Moreover, increased expression rates of VEGF in BK-treated neuroblastoma cells further support the hypothesis that this kinin is a pro-metastatic factor (Figures $\mathbf{3 A - C}$ ). BK induced a significant increase in VEGF gene expression in CHP-134, IMR32, and CHP-100 cells (Figure 3A) as well as of VEGF protein expression (Figure 3B). BK-treatment elevated VEGF protein density approximately three-fold, when compared to control experiments with CHP-100 cells (Figure 3C).

Matrix metalloproteinases (MMPs), especially MMP-2 and MMP-9, are responsible for the degradation of components of the basement membrane and extracellular matrix, thereby promoting tumor invasion (Aznavoorian et al., 1993; Curran and Murray, 2000; Rundhaug, 2005). BK treatment enhanced MMP-2 gene expression in CHP-134, IMR-32 and CHP-100 cell lines (Figure 4A). In addition to the gelatinolytic activity of stimulated MMP-2 (62 kDa), its latent MMP-2 form (72 $\mathrm{kDa})$ and the active form of MMP-9 $(82 \mathrm{kDa})$ in CHP-100 cells were detected by zymography assays (Figure 4B). Only MMP-2 activity was augmented upon treatment with BK, while activity and expression levels of MMP-9 were unchanged following BK treatment (Figures 4B,C).

Next, Alexa phalloidin immunofluorescence staining for the actin cytoskeleton, revealed notable morphological differences between BK-treated and untreated CHP-100 cells (Figure 5A), although overall staining intensity did not show any significant difference (Figure 5B). For quantitative analysis of changes structural of actin filaments (F-actin), cellular areas were identified, followed by measurement of filament areas and staining intensities using Strata Quest Software (TissueGnostics). In the control sample, there were much less filaments, but also cellular staining areas were smaller than in BK-treated samples. Hence, when the filament area was normalized to the cellular area, the total difference in the number of filaments was not 

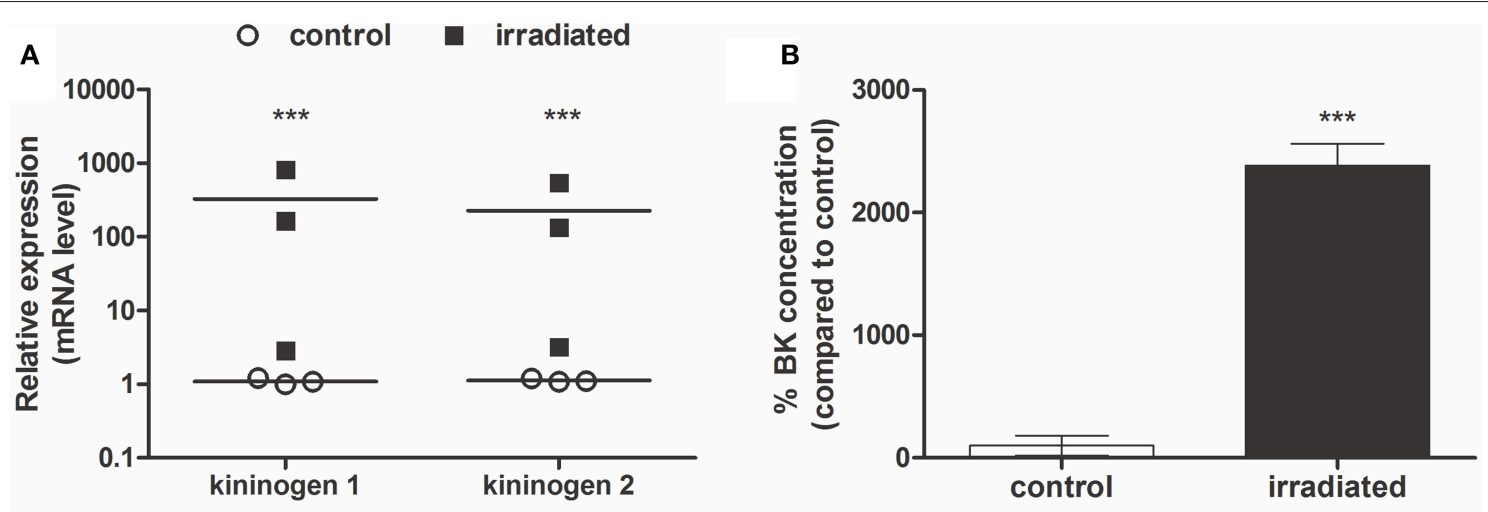

C

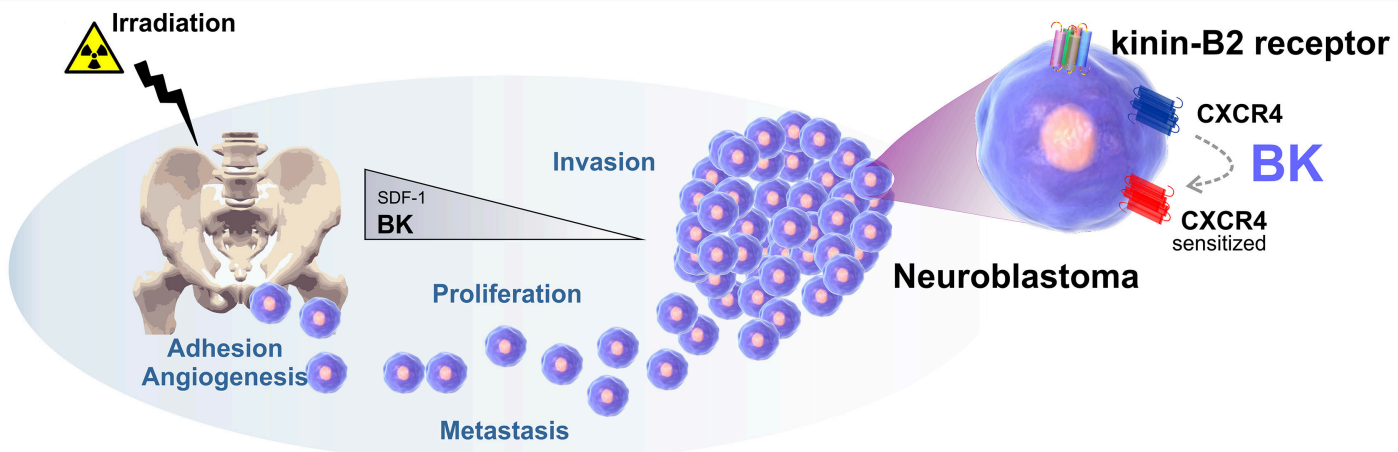

FIGURE 1 | Expression of Bradykinin in Bone Marrow. BK concentration and it precursor RNA level were determined in murine bone marrow lysates prepared from the animal $24 \mathrm{~h}$ after irradiation (1,000 cGy). (A) mRNA levels of kininogen 1 and kininogen 2. Measurements were performed for samples from three independent isolations. Each analysis was performed in triplicates. (B) BK levels in bone marrow of irradiated mice compared to non-irradiated mice (control). The data are shown as mean of six independent experiments and plotted as percentages compared to the control (100\%). ${ }^{* * *} p<0.001$ compared to control. (C) Mechanistic illustration of BK-promoted neuroblastoma metastasis. BK levels increase in the bone marrow of animals that received radiation, a situation mimicking radiotherapy during cancer treatment. In this case, the levels of SDF-1, the main chemo-attractor of hematopoietic stem cells to the bone marrow, is reduced. However, BK as priming agent sensitizes the SDF-1 receptor (CXCR4), also expressed by neuroblastoma cells, induces expression of metalloproteinase (MMP-2 and/or MMP-9) important for tumor invasion and VEGF, a key protein in the mechanism of angiogenesis, and enhances adhesion and proliferation of neuroblastoma cells.
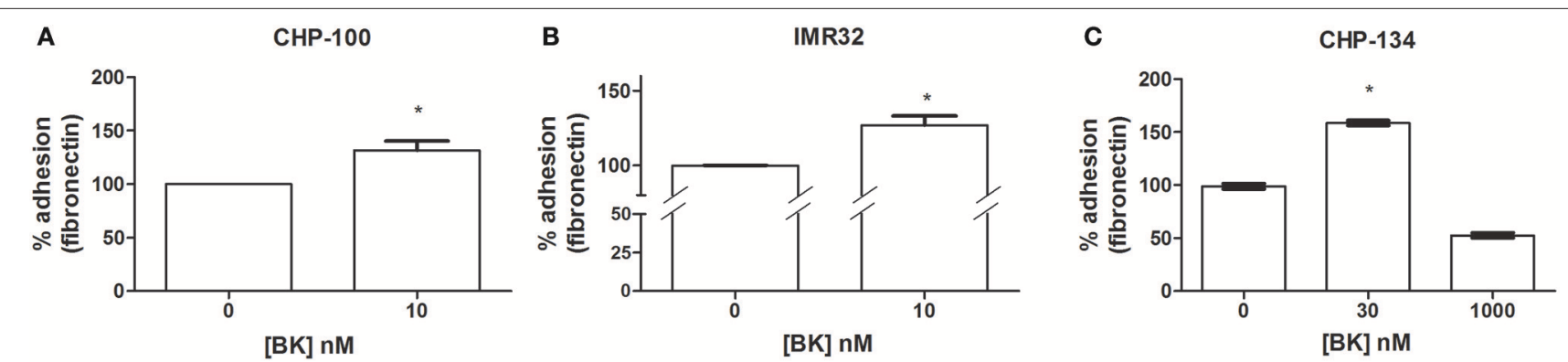

FIGURE 2 | Effects of Bradykinin on adhesion. Adhesion rates determined as binding rates to fibronectin-coated dishes were measured following $24 \mathrm{~h}$ of culturing of neuroblastoma cells in the absence or presence of BK. (A) CHP-100 and (B) IMR-32 treated with $10 \mathrm{nM}$ BK for $24 \mathrm{~h}$; and (C) CHP-134 treated with 30 or 1,000 nM BK. Control experiments were performed in the absence of BK (adhesion rates normalized to $100 \%$ ). ${ }^{*} p<0.05$ compared to untreated cells.

as expressive. The real difference, however, comes from the structural differences, as seen in the 3 quadrants UL (small filaments that are intensely stained), UR (large filaments that are intensely stained), and LR (large filaments that are weakly stained) (Figure 5C). In the absence of BK, neuroblastoma cells displayed smaller cellular areas with short F-actin filaments, but in its presence, cells revealed larger cellular area with longer filaments compared to control cells. Short branched filaments were more strikingly stained, reflecting BK-induced structural changes of F-actin (Figure 5D). 


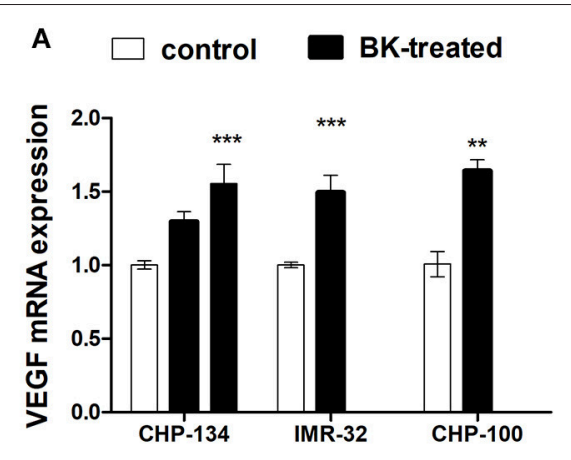

B CONTROL BK-TREATED
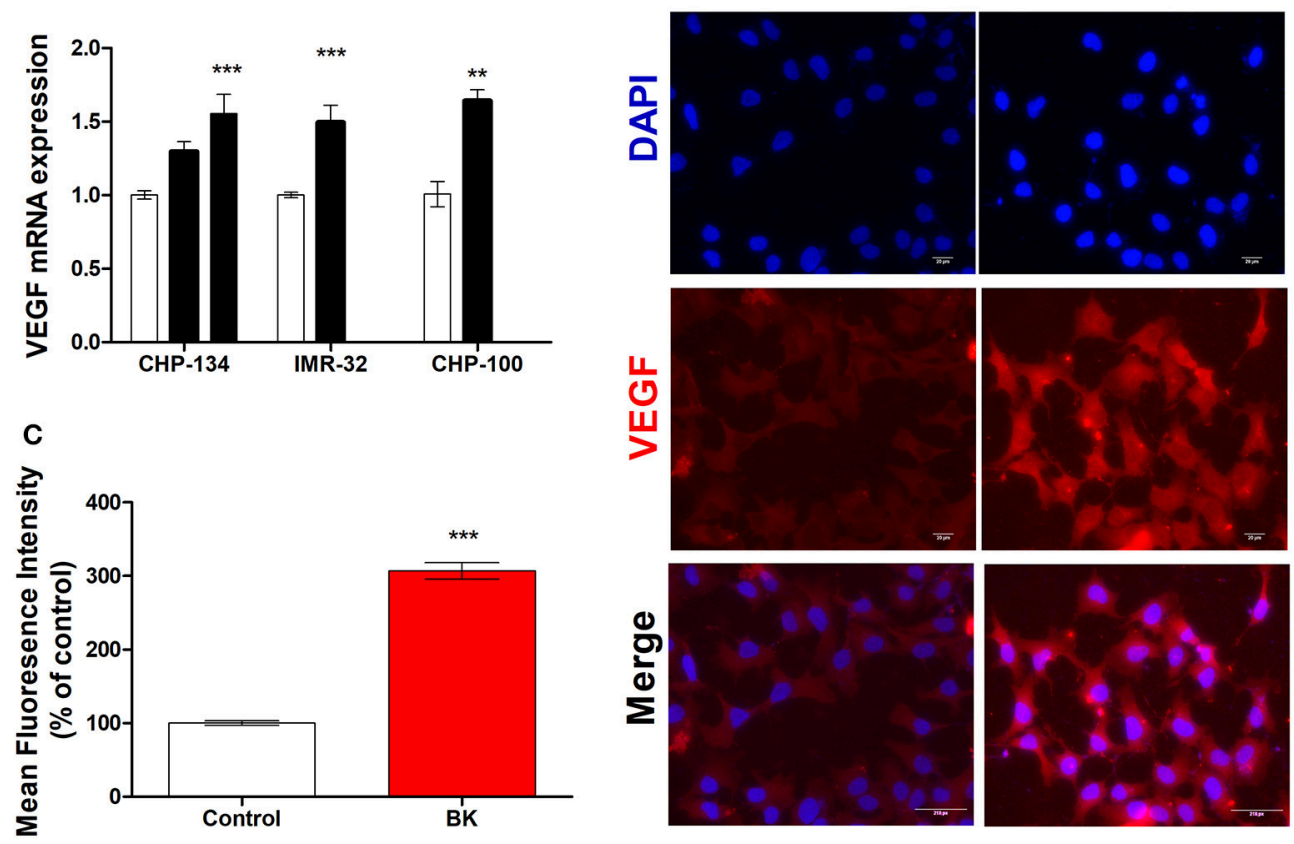

FIGURE 3 | VEGF expression in neuroblastoma cell lines. CHP-100 and IMR-32 cells were treated with $10 \mathrm{nM} \mathrm{BK}$ and CHP-134 with 30 (left black bar) or 1,000 nM (right black bar). (A) Analysis of mRNA expression of VEGF was performed for three cell lines by real time PCR, using the method of relative quantification. The experiment was done three times. (B) Immunostaining for VEGF protein expression in BK-treated CHP-100 cells. Scale bar, $20 \mu \mathrm{m}$. (C) Intensities of fluorescence were analyzed using ImageJ software: Cell Magic Wand Tool. The data represent mean values of three independent experiments. ${ }^{\star \star} p<0.01$ and ${ }^{\star \star \star} p<0.001$ compared to respective controls.

\section{Influence of Bradykinin and ATP on Chemotaxis of Neuroblastoma Cells}

We show here that BK treatment increased responsiveness of neuroblastoma cells to physiological SDF-1 concentrations. Various BK concentrations $(10,30,100,300$, and 1,000 nM) were screened for determining the optimal concentration for its priming effect on three neuroblastoma lines (CHP-134, IMR-32, and CHP-100) in response to 1,3 and $30 \mathrm{ng} / \mathrm{mL}$ SDF-1. The concentration of $10 \mathrm{nM} B K$ significantly increased the migration of IMR-32 and CHP-100 cells in the presence of low doses of SDF-1, while this BK concentration did not result in any significant alteration of migration in the presence of high doses of SDF-1. Maximal chemotaxis effects upon administration of $1 \mathrm{ng} / \mathrm{mL}$ SDF-1, visible as 250 and 300\% increases in migration rates compared to control experiments, were observed with IMR-32 and CHP-100 lines, respectively, when cells had been treated for $24 \mathrm{~h}$ with $10 \mathrm{nM}$ BK (Figures 6A,B). CHP-134 cells revealed biphasic effects for BK priming. Cells pretreated for $24 \mathrm{~h}$ with 30 or $1,000 \mathrm{nM}$ BK revealed highest priming rates, with $350 \%$ of control values, at all assayed doses of SDF-1 (Figure 6C). However, BK alone did not act as chemoattractant for neuroblastoma cells, neither at low $(10 \mathrm{nM})$ nor at high doses $(1,000 \mathrm{nM})$ (Figure 6D).

Increasing concentrations of ATP were applied together with $3 \mathrm{ng} / \mathrm{mL}$ SDF-1 in order to determine the priming effect of extracellular nucleotides in response to SDF-1. Such as BK, ATP exerted pronounced priming effects at all assayed concentrations (Figure 6E).

Of interest, $1 \mu \mathrm{M}$ ATP primed neuroblastoma cell migration toward the $\mathrm{BK}$ in relation to different $\mathrm{BK}$ concentrations, increasing chemotaxis of neuroblastoma cells by $200-300 \%$, showing maximal effects in response to $10 \mathrm{nM}$ BK stimulation (Figure 6F). ATP alone was chemoattractant for neuroblastoma cells if employed at supra-physiological doses (10 and $100 \mu \mathrm{M})$, as extracellular ATP is basically undetectable in healthy tissues (Junger, 2008). In contrast, cells primed with $10 \mathrm{nM}$ BK became responsive to up to $3 \mu \mathrm{M}$ physiological concentrations of ATP (Junger, 2008), while such priming effect was not observed at high doses of ATP (10 and $100 \mu \mathrm{M})$ (Figure 6G), indicating an interplay of BK and ATP signaling in cell chemotaxis.

\section{CXCR4 Are Expressed in Neuroblastoma Cell Lines}

CXCR4, the receptor for the chemokine stromal-derived factor 1 (SDF-1), mediates essential processes for tumor progression, such as metastasis. In order to investigate, whether CXCR4 expression was enhanced at the neuroblastoma cell surface in response to exogenously added BK explaining the increased responsiveness of these cells to SDF-1 in the chemotaxis assay, flow cytometry analysis was undertaken with CHP-134, IMR32, and CHP-100 cell lines. As shown in Figure 7, all tested cells lines expressed CXCR4, while cell surface expression levels 

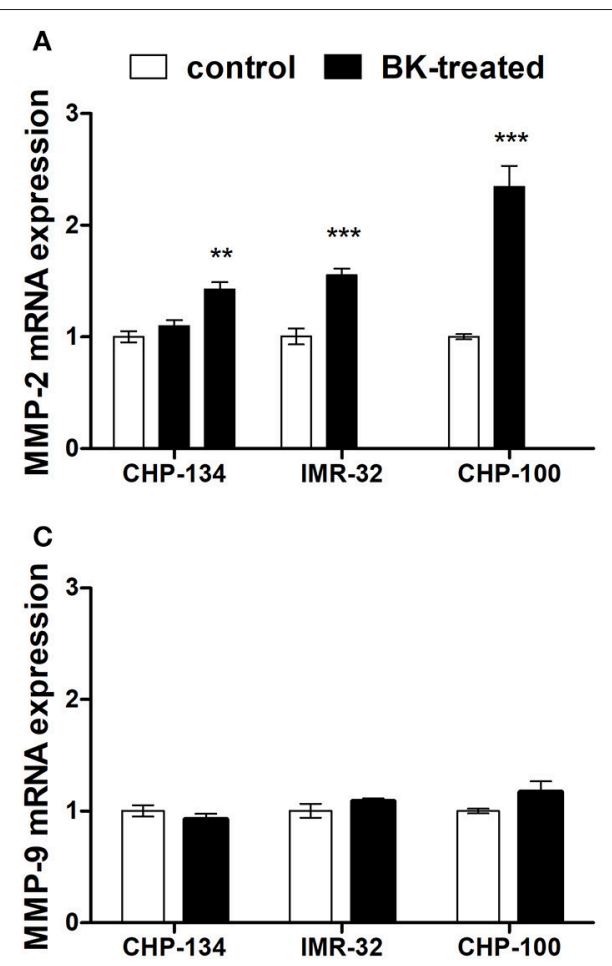

B

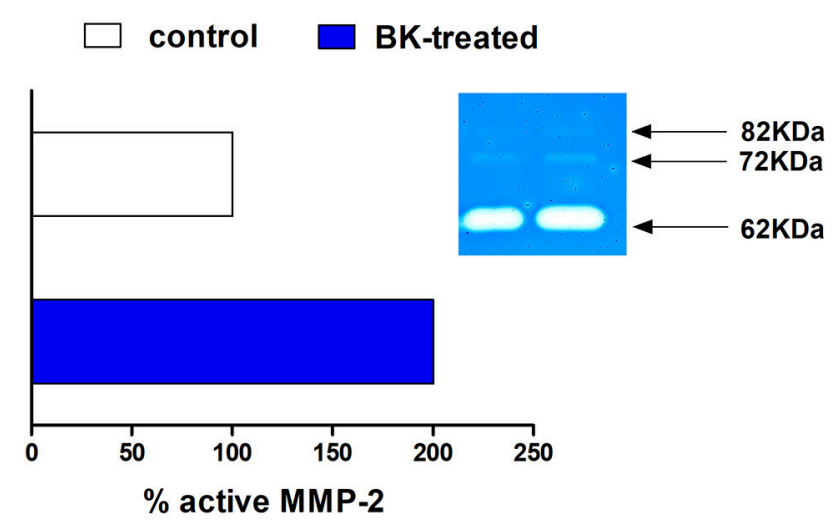

FIGURE 4 | Metalloproteinase expression and activity in neuroblastoma. (A) CHP-100 and IMR-32 cells were treated with 10 nM BK and CHP-134 with 30 (left black bar) or $1,000 \mathrm{nM}$ (right black bar) and analysis of mRNA expression of MMP-2 was performed for three cell lines by real time PCR, using the method of relative quantification. The experiment was done three times. (B) Graphic plot of the mean relative intensity regrading active form of MMP-2 (62 KDa) of the bands obtained in the zymography assay and representative gelatin zymogram: the active latent form of MMP-9 (82KDa), latent (72 KDa) and active forms (62 KDa) of MMP-2 were detected. (C) Analysis of mRNA expression of MMP-9 was performed by real time PCR. In this experiment CHP-134 was treated only with 1,000 nM BK. The data represent mean values of three independent experiments. ${ }^{* *} p<0.01$ and ${ }^{* \star *} p<0.001$ compared to respective controls.

of this chemokine receptor remained unchanged following $24 \mathrm{~h}$ treatment with increasing concentrations of BK.

\section{Bradykinin Regulates Expression Rates of Purinergic Receptors}

Interrelationships between purinergic and kinin signaling were observed for in vitro chemotaxis of neuroblastoma cells, such as in our earlier work in the context of neural migration and differentiation (Trujillo et al., 2012). In our present work, exposure of neuroblastoma cells for $24 \mathrm{~h}$ to $\mathrm{BK}$ decreased $\mathrm{P} 2 \mathrm{X} 4, \mathrm{P} 2 \mathrm{X} 5, \mathrm{P} 2 \mathrm{X} 6$, and $\mathrm{P} 2 \mathrm{Y} 2$ receptor subtype expression, while expression rates of P2X7, P2Y1, and P2Y12 subtypes in CHP100 cells were enhanced (Figures 8A,B). Visibly, exposure of neuroblastoma cells to $\mathrm{BK}$ also upregulated both $\mathrm{P} 2 \mathrm{X} 7$ receptor $\mathrm{A}$ and B splice variant expression in CHP-100 (Figure 8C) and only $\mathrm{P} 2 \mathrm{X} 7 \mathrm{~B}$ receptor variant expression in $\mathrm{SH}-\mathrm{SY} 5 \mathrm{Y}$ cells (Figure 8D). It is noteworthy that both cell lines originate from the metastatic $\mathrm{BM}$ site.

\section{Sensitization of CXCR4 and P2X7 Receptors by BK}

The specific effects of the SDF-1 are mediated by G-proteinlinked seven-trans-membrane domain receptors. A transient dose-dependent increase in $\left(\left[\mathrm{Ca}^{2+}\right]_{i}\right)$ occurs as an essential component of the signal transduction cascade activated upon binding of a chemokine to its receptor (Roy et al., 2017). Neuroblastoma cells responded with transient elevations of $\left[\mathrm{Ca}^{2+}\right]_{i}$, when stimulated with $30 \mathrm{ng} / \mathrm{mL}$ SDF-1. Exposure for $24 \mathrm{~h}$ to $10 \mathrm{nM}$ BK sensitized neuroblastoma cells to low doses of SDF-1 (3 ng/mL) (Figure 9A), suggesting that BK increases the sensitivity of CXCR4 responsiveness to SDF-1 facilitating its activation. Moreover, cells treated with BK showed augmented responses to $\mathrm{P} 2 \mathrm{X} 7$ receptor agonist Bz-ATP and ATP stimulation. Effects induced by both ATP and Bz-ATP were inhibited by A438079, a selective P2X7 receptor antagonist (Figure 9B).

\section{Bradykinin Induces Neuroblastoma Cell Proliferation}

P2X7 receptor activation in ACN neuroblastoma cells does not induce cell death, while driving proliferation (Raffaghello et al., 2006). Accordingly, in our hands, exposure to BK; $\mathrm{BK}+\mathrm{Bz}$-ATP or BK + ATP did not decrease cellular viability in at least three of the investigated neuroblastoma cell lines (Figures 10A-C). Similarly, P2X7 receptor-induced pore formation did not augment, when the same neuroblastoma cell lines had been pretreated with BK (Figures 10D-F). As expected, $\mathrm{BK}$ at $10-1,000 \mathrm{nM}$ concentrations promoted proliferation of both, CHP-134 (Figure 11A) and CHP-100 cells (Figure 11B). 


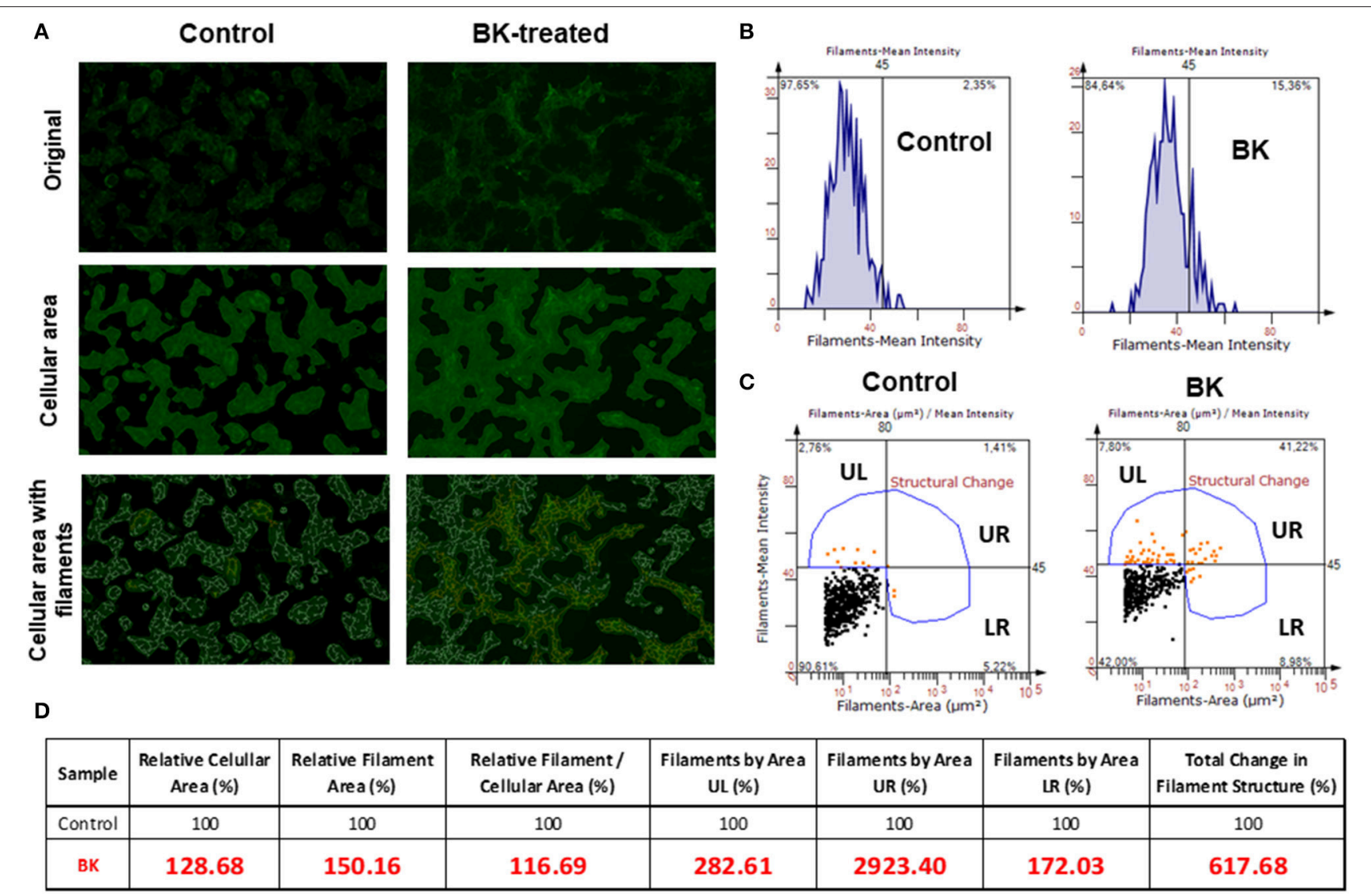

FIGURE 5 | Rearrangements of the actin cytoskeleton in neuroblastoma cells induced by Bradykinin. (A) Fluorescence microscopy images are representative of actin filament staining with Alexa Fluor 488 phalloidin (original); images with cell area demarcation and with outstanding filaments. (B) Representative histograms of fluorescence intensity of actin filaments of control and BK-treated CHP-100 cells. (C) Quantitative analysis of change in filament structure (fluorescence intensity X cellular area) in neuroblastoma cells treated with $10 \mathrm{nM} \mathrm{BK}$ compared to control using Strata Quest software. The quadrants were divided as UL (small filaments that are intensely stained), UR (large filaments that are intensely stained), and LR (large filaments that are weakly stained). (D) Table of relative values analyzed parameters to identify changes in filaments structure. The experiment was repeated three times.

Of interest, BK-promoted effects on the proliferation rate was significantly decreased in the presence of the P2X7 receptor antagonist A438079 (Figure 11C), suggesting that kininergicpurinergic signaling cross talking is required for BK-dependent cancer cell proliferation.

\section{Participation of BK and P2X7 Receptors in Site-Directed Spreading of Neuroblastoma Cells to Organs Expressing SDF-1}

Finally, the effects of $\mathrm{BK}$ and of $\mathrm{P} 2 \mathrm{X} 7$ receptor antagonism on metastatic dissemination of neuroblastoma cells to BM, liver and lungs were evaluated in short and long-term transplanted animal models. We tested, whether the treatment of neuroblastoma cells with $\mathrm{BK}$ and inhibition of $\mathrm{P} 2 \mathrm{X} 7$ receptor in nude mice affected the metastatic spread (seeding efficiency) of these cells to tissues expressing SDF-1 in a short-term metastatic model (Figure 12). We found that BK significantly increased the seeding efficiency of neuroblastoma cells in liver and BM and that this effect was significantly decreased after treatment of animals with the P2X7 receptor antagonist Brilliant Blue-G (BBG) (Figure 12A-C). We noticed that the seeding efficiency to the $\mathrm{BM}$ increased about 8 and 10 times for CHP-100 and SH-SY5Y lines, respectively, when cells had been treated with $\mathrm{BK}$ ex vivo (Figures 12A,B) and 25 times more for CHP-100 cells to the liver (Figure 12C) after $48 \mathrm{~h}$ of i.v. injection of cells into immunodeficient nude mice. However, when animals had been i.p. treated with the P2X7 receptor antagonist $\mathrm{BBG}$, neuroblastoma cells lack the ability to spread to these organs even when these had been ex vivo primed with BK (Figures 12A-C). In contrast, the spreading of neuroblastoma cells to the lungs showed no significant difference regardless if tumor cells had been primed with BK or treated with BBG (Figure 12D). A schematic illustration of these findings has been presented (Figure 12E).

In order to assess interrelationship of kinin and purinergic systems in a long-term animal model, nude mice were subcutaneously inoculated with BK-treated CHP-100 cells, then the animals were received i.p. BBG or saline every 2 days. Mice receiving saline developed palpable tumors within 10 days after inoculation, while tumor masses in mice injected with BBG 


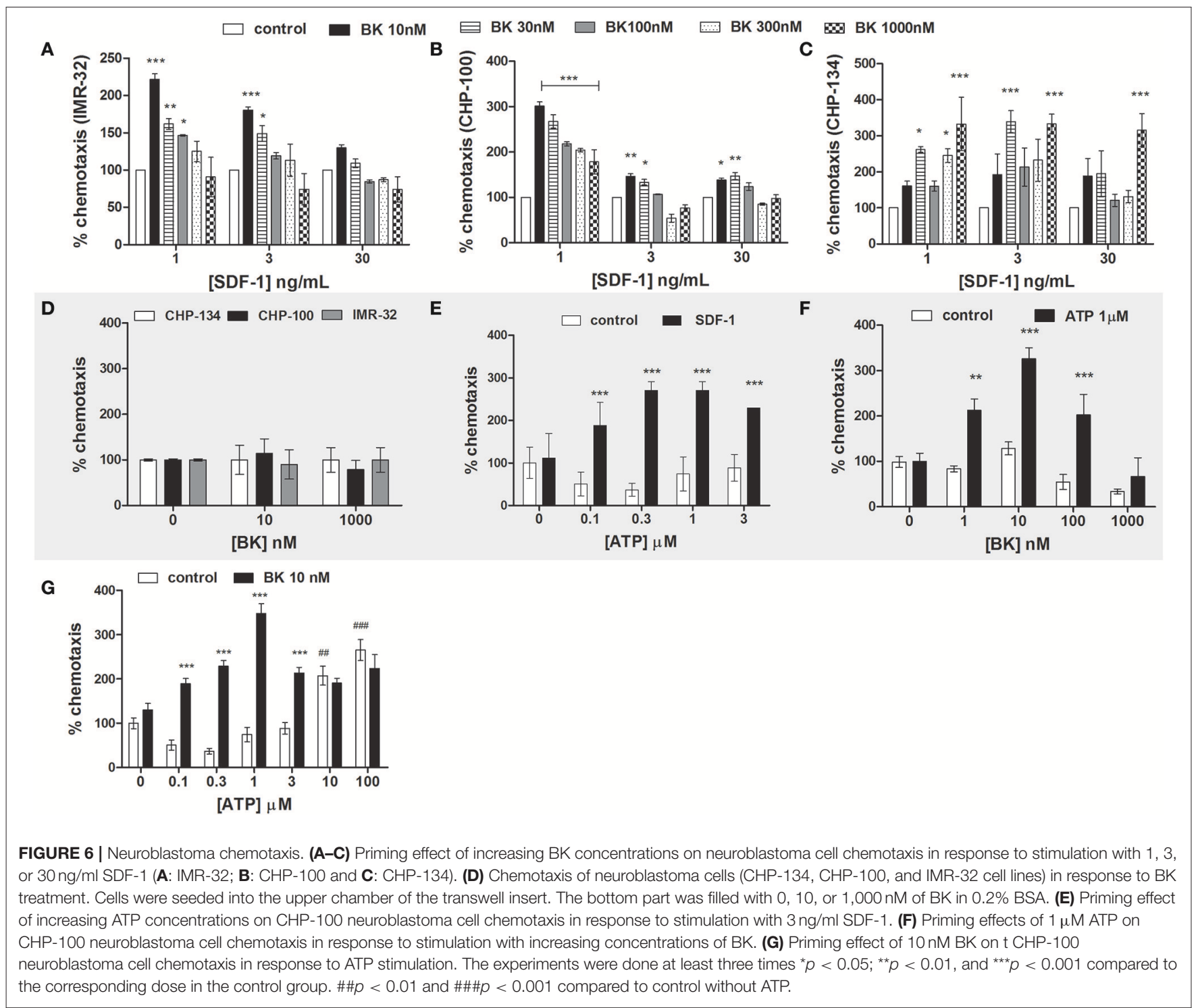

occurred later on day 15 (Figure 13A). Size and weight of tumors of saline-receiving animal was significantly larger than that of BBG-treated animals (Figures 13A-C). As expected, seeding efficiency to BM was significantly decreased with chronical treatment with BBG. This result corroborates with data of shortterm model (Figure 13D).

\section{DISCUSSION}

The pivotal role of the (SDF-1)/CXCR4 axis in BM metastasis has been described for various tumor types, including neuroblastoma (Russell et al., 2004; Kucia et al., 2005b). However, blocking of the SDF-1-CXCR4 axis does not prevent metastasis of cancer cells to the BM and other tissues expressing SDF-1, suggesting the involvement of other pro-metastatic factors as chemoattractants for tumor cells (Wysoczynski et al., 2007). Based on well-known side effects of chemotherapy and radiotherapy, mainly due to the leaking of inflammatory molecules from damaged organs, we propose BK and extracellularly acting ATP as potential prometastatic factors for neuroblastoma cells.

Previously, we reported that extracellular nucleotides are released during radio- and chemotherapy by the BM (Schneider et al., 2015). In the present study, we show that the transcript levels of BK precursor as well peptide BK concentration are significantly increased in BM from irradiated mice. These data corroborate with our hypothesis that molecules related to inflammation, such as BK and ATP, are released in large amounts by damaged BM due to unwanted effects of radio- and chemotherapy.

We have suggested that increased levels of BK and ATP point at a compensatory effect for metastasis of tumor cells to the BM, explaining why this tissue is the most common site for recurrence of several cancers (Coleman, 2001; Bacci et al., 2006), even when SDF-1 levels diminish after chemotherapy decreases due to an induced proteolytic environment (Ratajczak et al., 2013). 

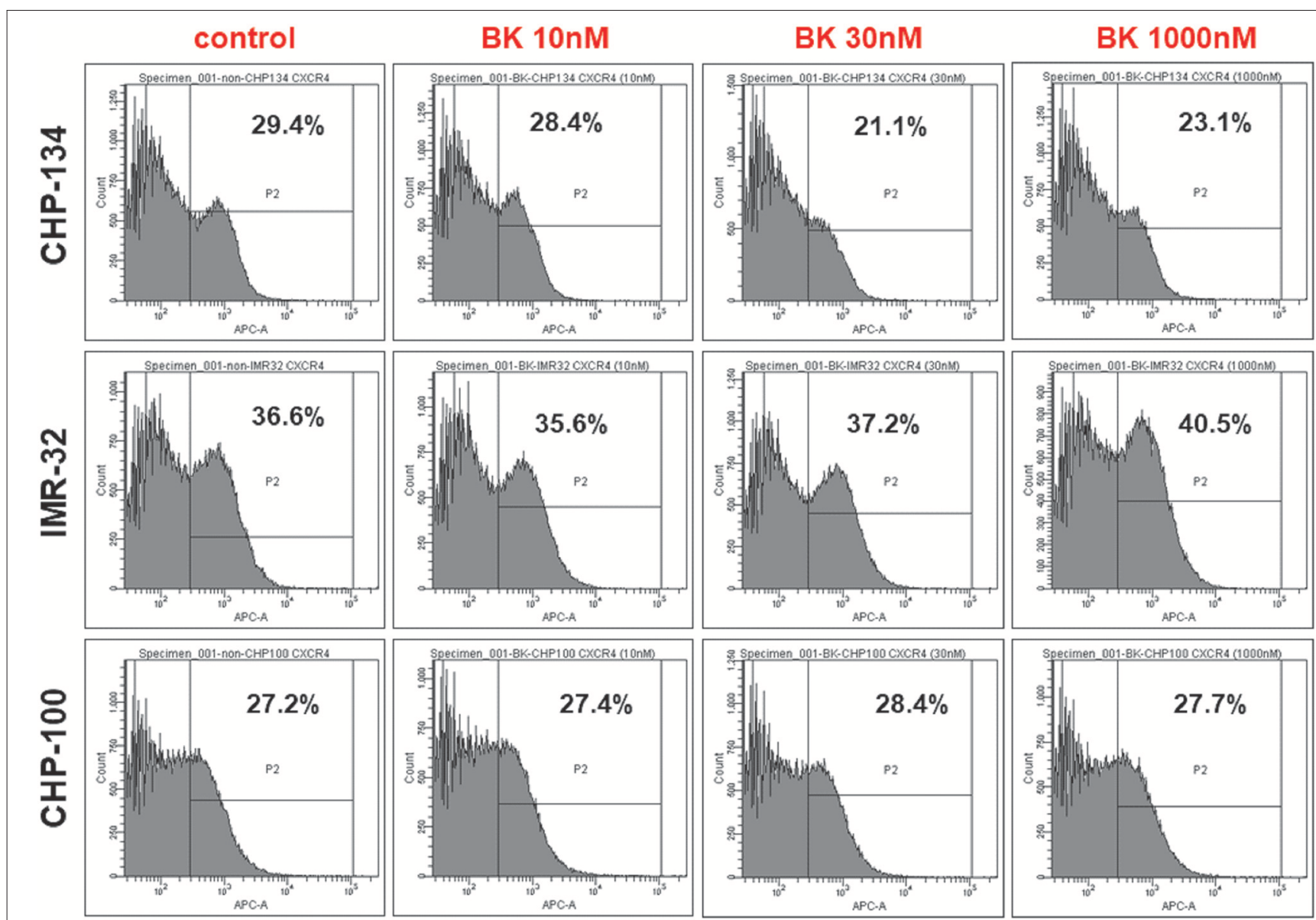

FIGURE 7 | Neuroblastoma cell lines express (C-X-C chemokine receptor type 4). Flow Cytometry Analysis of CXCR4+ cells in CHP-134, IMR-32, and CHP-100 cell lines under increasing BK concentrations. Data representative of three independent assays.

The pioneering discovery of the present study is the action of $\mathrm{BK}$, as a pro-metastatic factor, as well as its relationship with the SDF-1/CXCR4 axis and purinergic signaling. BK-mediated effects on neuroblastoma progression include increasing cell adhesion, promoting angiogenesis, and rearrangement of the cytoskeleton, in addition to proliferation induction and enhancement of neuroblastoma invasion capacity due to sensitization of both CXCR4 and P2X7B receptors.

In view of that, increased adhesiveness of neuroblastoma cells is important for the establishment of a physical connection between metastatic cells and BM. In agreement we report herein that BK increased the adhesion ability of neuroblastoma cells to fibronectin. BK is known to provoke formation of focal adhesions in quiescent cells, as it promotes phosphorylation of paxillin and Focal adhesion kinase (FAK) (Leeb-Lundberg et al., 1994). Focal adhesions are specialized anchoring sites found in cultured cells, where extracellular domains of integrins bind to extracellular matrix proteins such as fibronectin (Burridge, 1988). This interaction results in the aggregation of integrins and their intracellular association with cytoskeletal proteins by domains that anchor filament bundles of polymerized actin (stress fibers) at these sites. FAK activation also is involved in regulating cell responses to environmental stimuli to influence tumor cell migration (Megison et al., 2013), through signal-mediated effects on actin organization. Here, we have shown that BK promoted structural changes of the actin cytoskeleton. This role of FAK in controlling actin-remodeling dynamics during tumor cell adhesion and motility is congruous with the observations that perturbed FAK expression and activity correlates with increased clinical progression into highly malignant and metastatic phenotypes (De Vicente et al., 2013).

For metastasis, invasion is an important and complex process involving several coordinated stages: egress of cancer cells from primary tumor, establishing new contacts with the environment, degradation and remodeling of the extracellular matrix and migration of tumor cells to new tissue locations (Rao, 2003). In this process, matrix metalloproteinases (MMP), especially MMP-2 and MMP-9, are crucial for extracellular matrix remodeling and, consequently, the tumor invasiveness. BK treatment resulted in increased expression and activity of MMP-2 in neuroblastoma cells. The proteolysis of the basement membrane and extracellular matrix is a prerequisite for the 

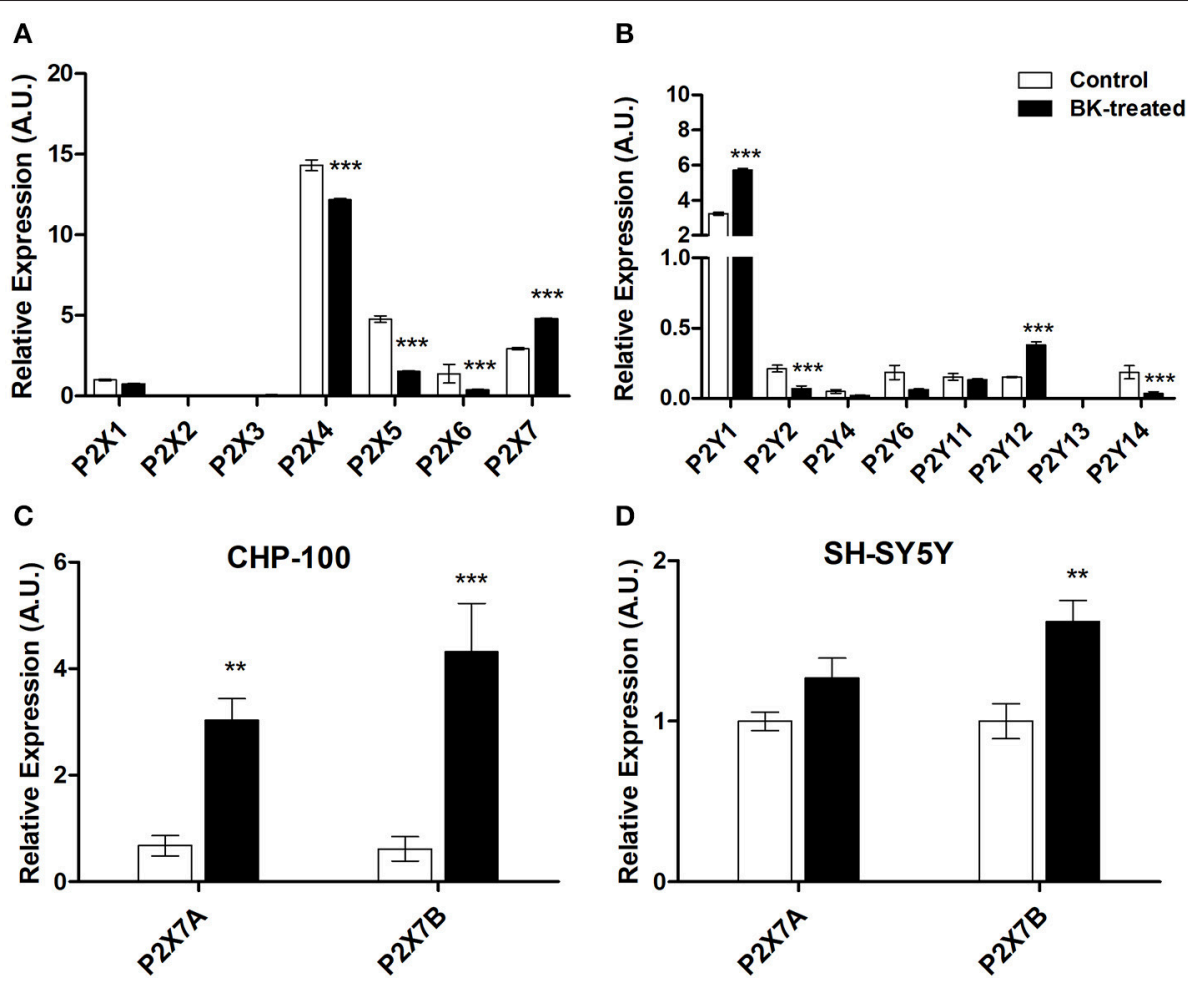

FIGURE 8 | P2 Purinergic receptors expressed by neuroblastoma cells under BK treatment. Differential gene expression of P2 purinergic receptors was assessed by real-time PCR in CHP-100 and SH-SY5Y cells maintained in BSA 0.2\% for $24 \mathrm{~h}$ with or without 10 or $30 \mathrm{nM}$ BK, respectively, and normalized using glyceraldehyde 3-phosphate dehydrogenase (GAPDH) mRNA levels. mRNA expression changes of (A) P2X receptor subtypes; (B) P2Y receptor subtypes; (C) P2X7 isoforms A and $\mathrm{B}$ in CHP-100 cells; (D) P2X7 isoforms A and B in SH-SY5Y cells. The obtained data were compared with mRNA levels of non-treated CHP-100 cells (control) expressed as arbitrary units (A.U.).** $p<0.01$ and ${ }^{* * *} p<0.001$.
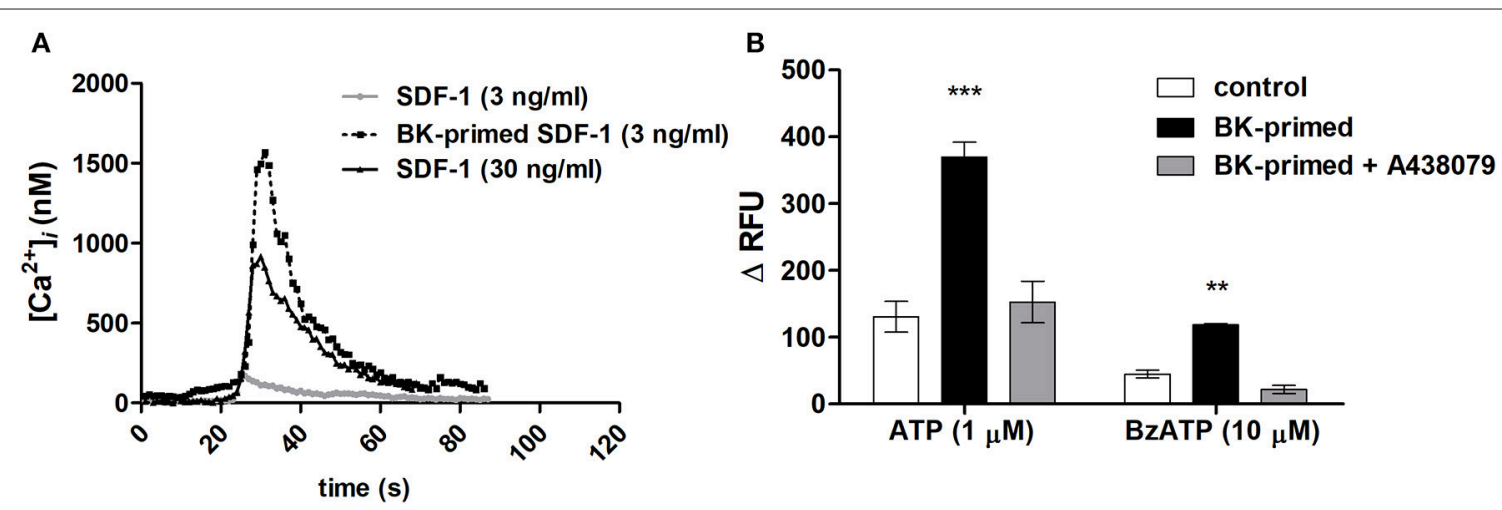

FIGURE 9 | Elevations of $\left[\mathrm{Ca}^{2+}\right]_{i}$ levels in neuroblastomas cells after stimulation with SDF-1, ATP or Bz-ATP. Measurements were performed with cells primed for $24 \mathrm{~h}$ with $10 \mathrm{nM} \mathrm{BK}$ and compared to those obtained with untreated control cells. (A) Representative traces of $\left[\mathrm{Ca}^{2+}\right]_{j}$ transients upon SDF-1 (3 or 30 ng/ml) application determined by calcium imaging. (B) For microfluorimetry-based $\left[\mathrm{Ca}^{2+}\right]_{i}$ measurements, $1 \mu \mathrm{M}$ ATP or $10 \mu \mathrm{M}$ Bz-ATP were used to stimulate control cells or cells primed for $24 \mathrm{~h}$ with $10 \mathrm{nM}$ BK. A438079 $(5 \mu \mathrm{M})$ was used to determine participation of the P2X7 receptor subtype in purinergic receptor responses. Data are presented as the difference between maximal and minimal relative fluorescence units $(\Delta \mathrm{RFU}) .{ }^{\star \star} p<0.01$ and ${ }^{\star \star \star} p<0.001$.

formation of new vessels that provide oxygen and nutrients as well as a novel routes for neoplastic cells to enter circulation and reach distant organs (Rundhaug, 2005; Folkman, 2007).

Among the multiple effects of $\mathrm{BK}$ on neuroblastoma cells, we have observed that BK induced VEGF expression.
VEGF promotes angiogenesis with the growth of new blood vessels inside the tumor. These vessels nourish the tumors and at the same time provide and facilitate the emergence of metastasis. The increase in VEGF secretion could be a consequence of BK-dependent $\mathrm{P} 2 \mathrm{X} 7$ receptor overexpression, as 

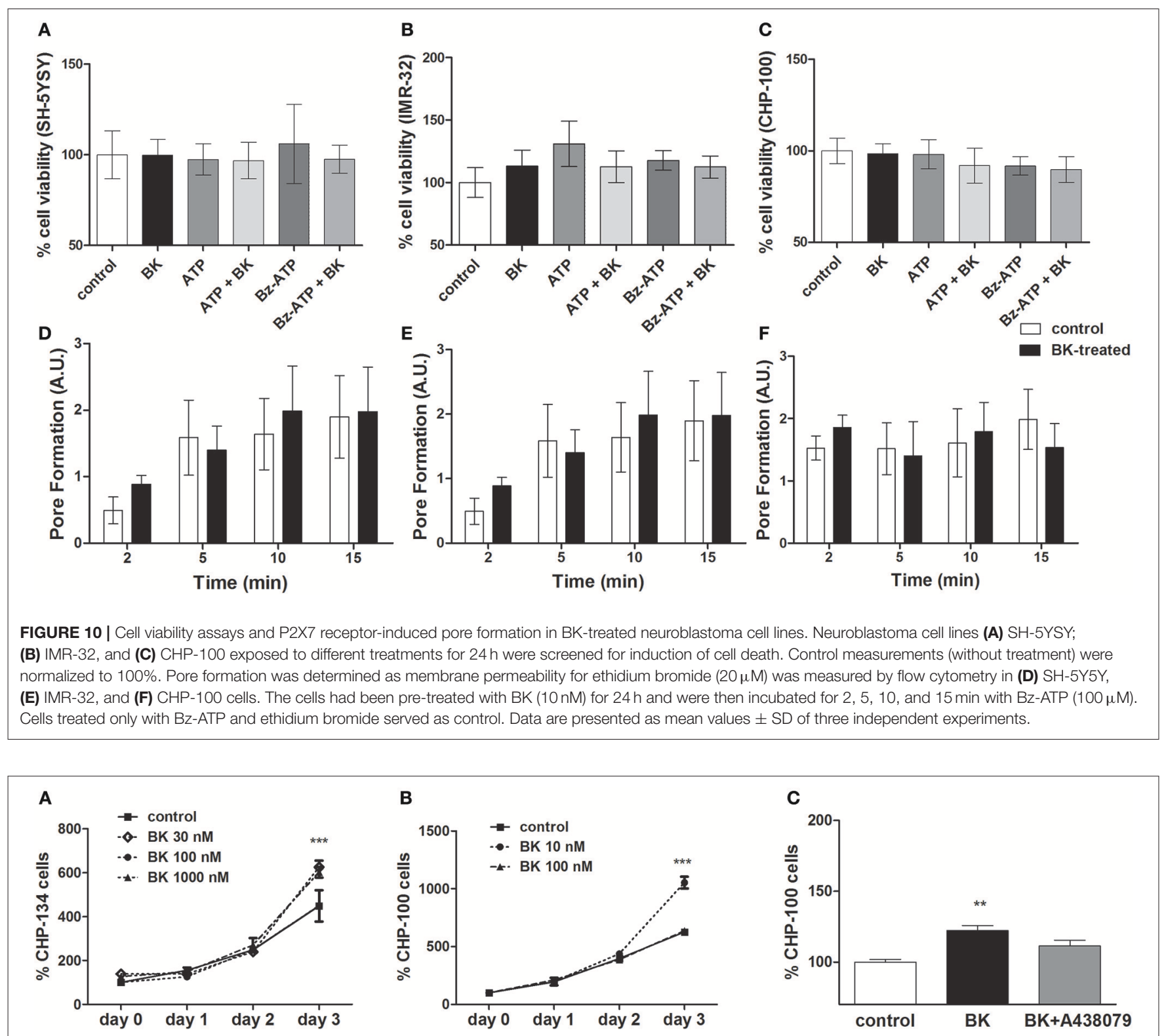

FIGURE 11 | Effects of bradykinin on proliferation. Proliferation kinetics were assessed for 3 days following BK addition: (A) CHP-134 in the absence (control) or presence of 30, 100, or 1,000 nM BK. (B) CHP-100 in the absence (control) or presence of 10 or $100 \mathrm{nM} \mathrm{BK}$. (C) Proliferation rate on day 3 : CHP-100 in the absence (control), presence of $10 \mathrm{nM}$ BK or presence of BK $10 \mathrm{nM}$ and $5 \mu \mathrm{M}$ A438079, a selective P2X7 receptor antagonist. Data represent mean values \pm S.D. of four independent experiments. ${ }^{* *} p<0.01 ;{ }^{* *} p<0.001$ compared to control.

this purinergic receptor subtype was shown to cause a rise in tumor vascularization via VEGF secretion (Adinolfi et al., 2012; Amoroso et al., 2015).

We have observed that $\mathrm{BK}$ increases the sensitivity of CXCR4 in response to SDF-1 and facilitates its activation as shown by augmented amplitudes of $\left[\mathrm{Ca}^{2+}\right]_{i}$ transients. The BK-induced responsiveness to SDF-1 could result from lipid rafts formation, a relevant mechanism for the neuroblastoma model (Palacios-Moreno et al., 2015; Ding and Zajac, 2016), since even after $24 \mathrm{~h}$ of contact with neuroblastoma lines, BK at various concentrations $(10,30,100,300$, and $1,000 \mathrm{nM})$ did not alter CXCR4 expression levels, as evaluated by flow cytometry. However, we demonstrated that BK-treated neuroblastoma cells increased expression levels of P2Y1 and P2X7 receptors. These purinergic receptor subtypes are directly related to the metastasis of cancer cells (Shafat et al., 2006; Roger and Pelegrin, 2011).

Although BK or ATP alone did not exert any chemotactic effects on neuroblastoma cell lines, we demonstrate here their effects on inducing striking chemotaxis by increasing the response of those cells to low physiological-relevant doses of SDF-1, which resemble those encountered in endogenous physiological conditions (Junger, 2008). 


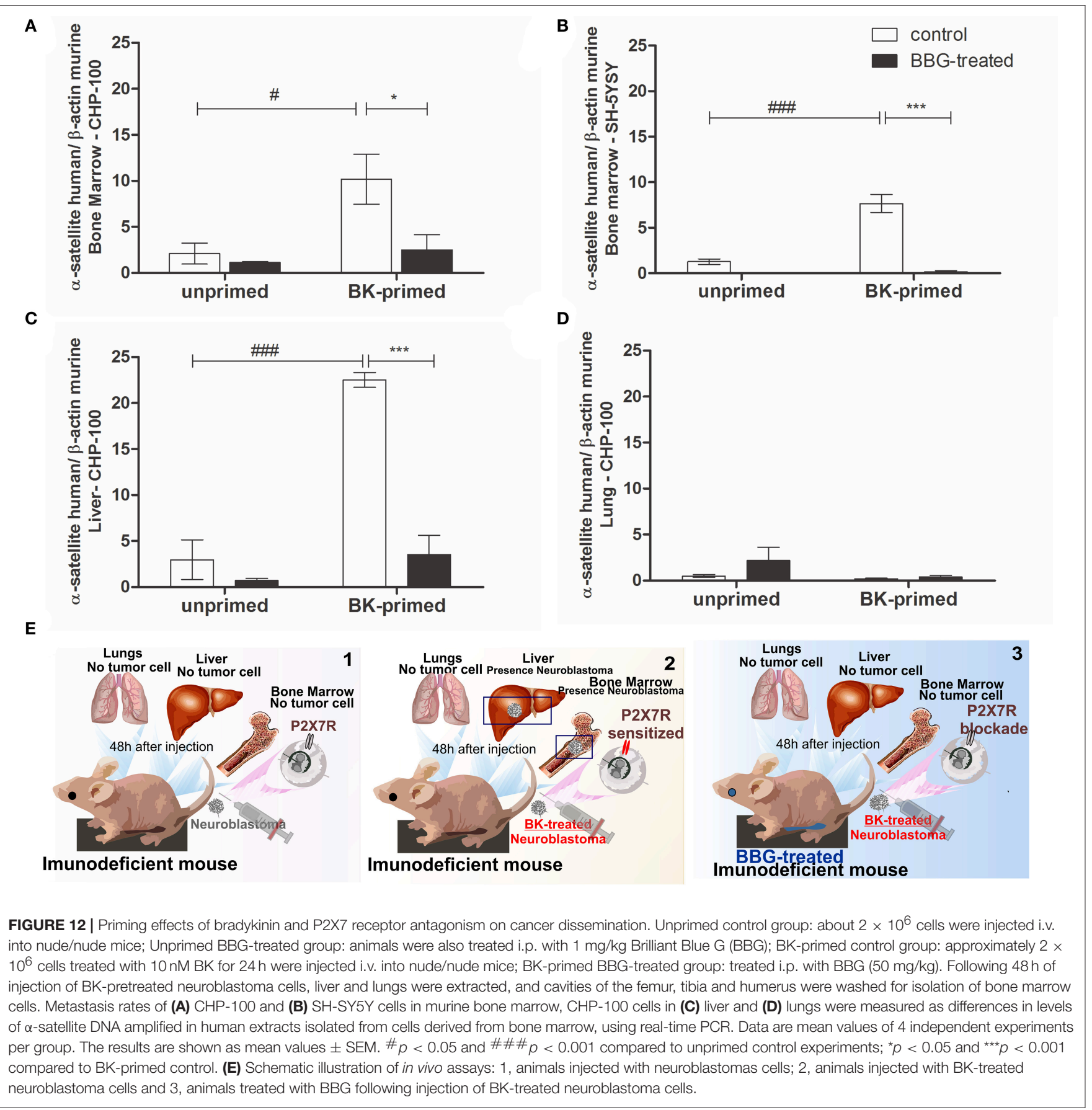

We have paid special attention to the interplay between $\mathrm{P} 2 \mathrm{X} 7$ receptor and $\mathrm{BK}$ actions, since several recent reports have correlated $\mathrm{P} 2 \mathrm{X} 7$ receptor activity with carcinogenesis and, interestingly, BK-promoted effects were counteracted by pharmacological blockade of $\mathrm{P} 2 \mathrm{X} 7$ receptor activity, both in vitro and in vivo. Upon BK treatment, sensibility toward the P2X7 agonist was increased, and this effect was reversed following application of a selective $\mathrm{P} 2 \mathrm{X} 7$ receptor antagonist. The influence of $\mathrm{BK}$ on $\mathrm{P} 2 \mathrm{X} 7$ receptor activity may explain its role and mechanism in promoting tumor cell dissemination, as different studies point at the $\mathrm{P} 2 \mathrm{X} 7$ receptor as an important promoter of invasiveness (Jelassi et al., 2011).

Moreover, BK treatment increased the expression levels of the only two known active human isoforms of the $\mathrm{P} 2 \mathrm{X} 7$ receptor: $\mathrm{P} 2 \mathrm{X} 7 \mathrm{~A}$ and P2X7B. Although little is known about P2X7B isoform expression in physio-pathological conditions, it is clear that this truncated version of the $\mathrm{P} 2 \mathrm{X} 7$ receptor retains the growth promoting activity of the full length $\mathrm{P} 2 \mathrm{X} 7 \mathrm{~A}$ protein while losing the pro-apoptotic function (Adinolfi et al., 2010; Giuliani et al., 2014). Therefore, it is tempting to speculate that, the 


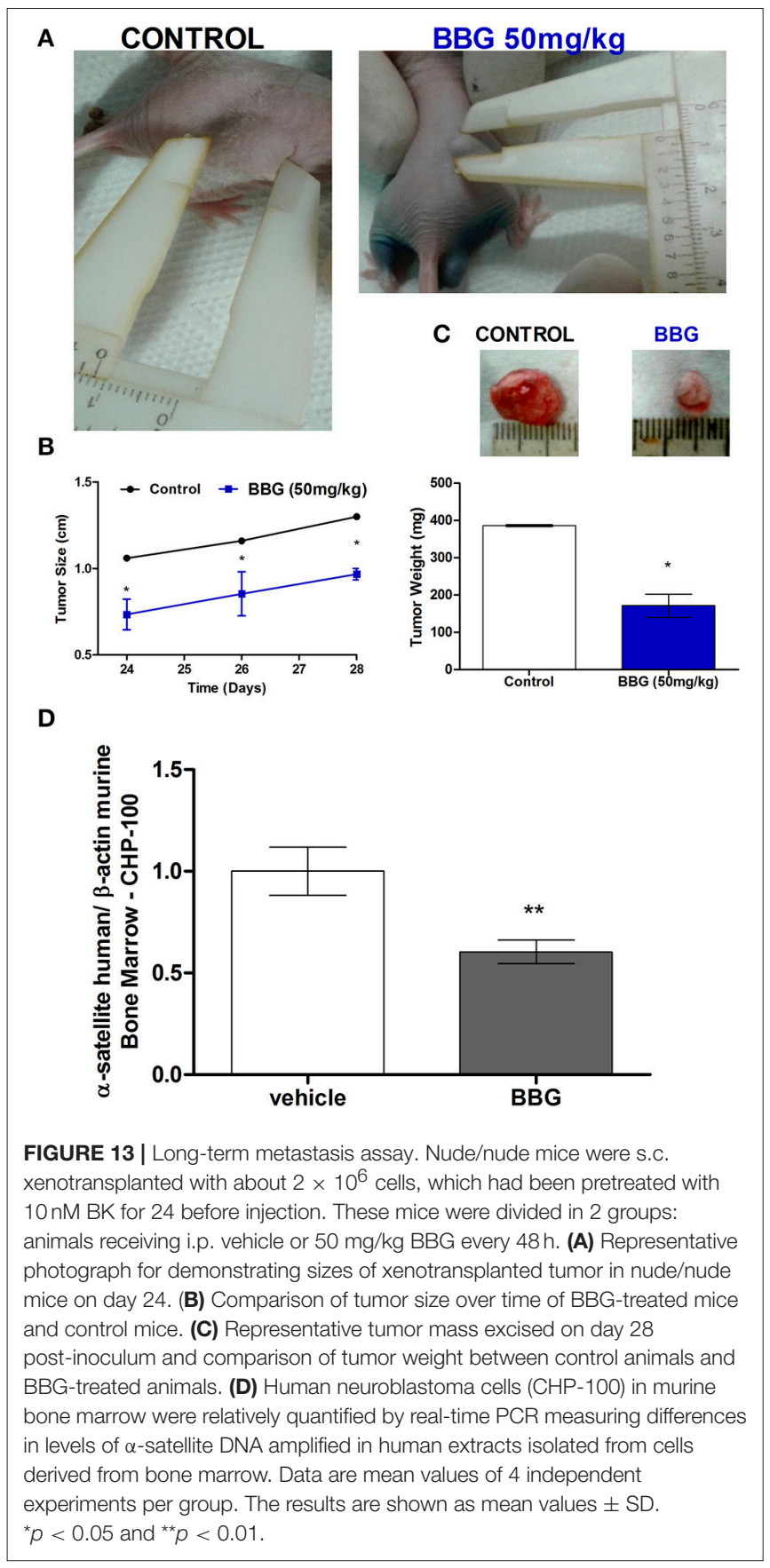

expression of the P2X7B isoform will be more advantageous for tumor growth as compared to the $\mathrm{P} 2 \mathrm{X} 7 \mathrm{~A}$ one. This hypothesis is further supported by recent data of Giuliani et al. showing that, in osteosarcoma, P2X7B isoform overexpression associates to increased tumor cell proliferation as compared to the P2X7A isoform (Giuliani et al., 2014).

Accordingly, we have gathered evidence that $\mathrm{BK}$ treatment of neuroblastoma cells favors the upregulation of P2X7B vs. the P2X7A isoform. BK prompts cell proliferation; however, it does not decrease cell viability nor increases
$\mathrm{P} 2 \mathrm{X} 7$ receptor pore activity associated to the $\mathrm{P} 2 \mathrm{X} 7 \mathrm{~A}$ isoform. Furthermore, BK-induced proliferation was significantly decreased by $\mathrm{P} 2 \mathrm{X} 7$ receptor antagonism, suggesting that BK could upregulate $\mathrm{P} 2 \mathrm{X} 7$ receptor-dependent signaling pathways leading to neuroblastoma growth (Amoroso et al., 2015). Moreover, BK-induced P2X7B isotype expression would allow neuroblastoma cells to exploit the high extracellular ATP concentration in the BM as a growth and seeding stimulus, rather than as a death signal.

Finally, we show here that BK promotes seeding of neuroblastoma cells in specific organs, being in line with results obtained in vitro. Human neuroblastoma cells were not detected in the lungs indicating preference of metastatic cancer cell migration to the $\mathrm{BM}$ and liver. This emphasizes the Paget's "seed and soil" hypothesis describing the interaction between the tumor cell and its environment in order for metastasis to occur (Paget, 1889). Furthermore, an interrelationship between purinergic and kinin systems was confirmed in vivo, where spreading of human neuroblastoma cells treated with BK to BM and liver was abolished or drastically reduced in BBG-treated nude mice compared to animals which had received a control solution. These data provide evidence for a novel mechanism of crosstalk between P2X7 and kinin signaling in the metastatic process.

The effect of $\mathrm{P} 2 \mathrm{X} 7$ receptor blockade on BK-induced seeding to $\mathrm{BM}$ was also observed in a long-term animal model. The chronic treatment of BBG led to a significant reduction in seeding efficiency of neuroblastoma cells. According to the literature, it also caused a delay in tumor growth, reflected by smaller size and lower weight of tumors of BBG-treated mice, when compared to control mice (Ryu et al., 2011).

In summary, our findings indicate that kinin and purinergic signaling systems are important for dissemination and metastasis of neuroblastoma to the BM. Therefore, molecular strategies to inhibit those signaling pathway, together with the SDF1/CXCR4 axis blockade, could lead to the development of novel more efficient anti-metastatic therapies to complement the conventional chemotherapy and radiotherapy in preventing the metastatic spread of neuroblastoma and other types of cancer.

\section{AUTHOR CONTRIBUTIONS}

GS, EA, EO, EF, TG, JC-V, PM, FC, AS, MP, and CL performed the experiments; CL summarized the literature and drafted the manuscript; HU, EA, CL, and US revised and edited the manuscript. HU, CL, GS, and MR supervised the work; HU and CL initiated, finalized, and submitted the manuscript.

\section{FUNDING}

The work was supported by grants awarded by São Paulo Research Foundation (FAPESP Project No. 2012/50880-4 and 2015/19128-2) and the Brazilian National Council for Scientific and Technological Development (CNPq Project No. 486294/2012-9 and 467465/2014-2), Brazil, to HU Doctoral 
thesis research of EF and TG was supported by FAPESP. MP acknowledges a postdoctoral fellowship from FAPESP, Brazil. NIH grants 2R01 DK074720 and R01HL112788 to MR are acknowledged. EA was supported by MFAG 11630 and IG16812 from the Italian Association for Cancer Research (AIRC) and institutional funds from the University of Ferrara.

\section{REFERENCES}

Adinolfi, E., Callegari, M. G., Ferrari, D., Bolognesi, C., Minelli, M., Wieckowski, M. R., et al. (2005). Basal activation of the P2X7 ATP receptor elevates mitochondrial calcium and potential, increases cellular ATP levels, and promotes serum-independent growth. Mol. Biol. Cell 16, 3260-3272. doi: 10.1091/mbc.E04-11-1025

Adinolfi, E., Capece, M., Amoroso, F., De Marchi, E., and Franceschini, A. (2015). Emerging roles of P2X receptors in cancer. Curr. Med. Chem. 22, 878-890. doi: 10.2174/0929867321666141012172913

Adinolfi, E., Cirillo, M., Woltersdorf, R., Falzoni, S., Chiozzi, P., Pellegatti, P., et al. (2010). Trophic activity of a naturally occurring truncated isoform of the P2X7 receptor. FASEB J. 24, 3393-3404. doi: 10.1096/fj.09-153601

Adinolfi, E., Raffaghello, L., Giuliani, A. L., Cavazzini, L., Capece, M., Chiozzi, P., et al. (2012). Expression of P2X7 receptor increases in vivo tumor growth. Cancer Res. 72, 2957-2969. doi: 10.1158/0008-5472.CAN-11-1947

Amoroso, F., Capece, M., Rotondo, A., Cangelosi, D., Ferracin, M., Franceschini, A., et al. (2015). The P2X7 receptor is a key modulator of the PI3K/GSK3 $\beta / \mathrm{VEGF}$ signaling network: evidence in experimental neuroblastoma. Oncogene 34, 5240-5251. doi: 10.1038/onc.2014.444

Aznavoorian, S., Murphy, A. N., Stetler-Stevenson, W. G., and Liotta, L. A. (1993). Molecular aspects of tumor cell invasion and metastasis. Cancer 71, 1368-1383. doi: 10.1002/1097-0142(19930215)71:4\&lt;1368::AID-CNCR2820710432\&gt;3. $0 . \mathrm{CO} ; 2-\mathrm{L}$

Bacci, G., Longhi, A., Ferrari, S., Mercuri, M., Versari, M., and Bertoni, F. (2006). Prognostic factors in non-metastatic Ewing's sarcoma tumor of bone: an analysis of 579 patients treated at a single institution with adjuvant or neoadjuvant chemotherapy between 1972 and 1998. Acta Oncol. 45, 469-475. doi: 10.1080/02841860500519760

Burnstock, G. (2007). Purine and pyrimidine receptors. Cell. Mol. Life Sci. 64, 1471-1483. doi: 10.1007/s00018-007-6497-0

Burridge, K. (1988). Focal adhesions: transmembrane junctions between the extracellular matrix and the cytoskeleton. Annu. Rev. Cell Dev. Biol. 4, 487-525. doi: 10.1146/annurev.cb.04.110188.002415

Coleman, R. E. (2001). Metastatic bone disease: clinical features, pathophysiology and treatment strategies. Cancer Treat. Rev. 27, 165-176. doi: $10.1053 /$ ctrv.2000.0210

Curran, S., and Murray, G. I. (2000). Matrix metalloproteinasesmolecular aspects of their roles in tumour invasion and metastasis. Eur. J. Cancer 36, 1621-1630. doi: 10.1016/S0959-8049(00)00156-8

da Costa, P. L., Sirois, P., Tannock, I. F., and Chammas, R. (2014). The role of kinin receptors in cancer and therapeutic opportunities. Cancer Lett. 345, 27-38. doi: 10.1016/j.canlet.2013.12.009

De Vicente, J. C., Rosado, P., Lequerica-Fernández, P., Allonca, E., Villallaín, L., and Hernández-Vallejo, G. (2013). Focal adhesion kinase overexpression: correlation with lymph node metastasis and shorter survival in oral squamous cell carcinoma. Head Neck 35, 826-830. doi: 10.1002/hed. 23038

Ding, Z., and Zajac, J. M. (2016). Cholesterol-rich lipid rafts are involved in neuropeptide FF anti-nociceptin/orphanin FQ effect. J. Neurochem. 136, 778-790. doi: 10.1111/jnc. 13450

Di Virgilio, F., Falzoni, S., Giuliani, A. L., and Adinolfi, E. (2016). P2 receptors in cancer progression and metastatic spreading. Curr. Opin. Pharmacol. 29, 17-25. doi: 10.1016/j.coph.2016.05.001

Folkman, J. (2007). Is angiogenesis an organizing principle in biology and medicine? J. Pediatr. Surg. 42, 1-11. doi: 10.1016/j.jpedsurg.2006.09.048

Geminder, H., Sagi-Assif, O., Goldberg, L., Meshel, T., Rechavi, G., Witz, I. P., et al. (2001). A possible role for CXCR4 and its ligand, the CXC chemokine stromal cell-derived factor-1, in the development of bone marrow metastases in neuroblastoma. J. Immunol. 167, 4747-4757. doi: 10.4049/jimmunol.167.8.4747

Giuliani, A. L., Colognesi, D., Ricco, T., Roncato, C., Capece, M., Amoroso, F., et al. (2014). Trophic activity of human P2X7 receptor isoforms A and B in osteosarcoma. PLoS One 9:e107224. doi: 10.1371/journal.pone.0107224

Jankowski, K., Kucia, M., Wysoczynski, M., Reca, R., Zhao, D., Trzyna, E., et al. (2003). Both Hepatocyte Growth Factor (HGF) and stromal-derived factor1 regulate the metastatic behavior of human rhabdomyosarcoma cells, but only HGF enhances their resistance to radiochemotherapy. Cancer Res. 63, 7926-7935.

Jelassi, B., Chantôme, A., Alcaraz-Pérez, F., Baroja-Mazo, A., Cayuela, M. L., Pelegrin, P., et al. (2011). P2X 7 receptor activation enhances SK3 channelsand cystein cathepsin-dependent cancer cells invasiveness. Oncogene 30, 2108-2122. doi: 10.1038/onc.2010.593

Junger, W. G. (2008). Purinergic regulation of neutrophil chemotaxis. Cell. Mol. Life Sci. 65, 2528-2540. doi: 10.1007/s00018-008-8095-1

Kucia, M., Ratajczak, J., and Ratajczak, M. Z. (2005a). Bone marrow as a source of circulating CXCR4+ tissue-committed stem cells. Biol. Cell 97, 133-146. doi: 10.1042/BC20040069

Kucia, M., Reca, R., Miekus, K., Wanzeck, J., Wojakowski, W., JanowskaWieczorek, A., et al. (2005b). Trafficking of normal stem cells and metastasis of cancer stem cells involve similar mechanisms: pivotal role of the SDF-1-CXCR4 axis. Stem Cells 23, 879-894. doi: 10.1634/stemcells.2004-0342

Lameu, C., Hayashi, M., a, F., Guerreiro, J. R., Oliveira, E. F., and Lebrun, I., Pontieri, V., et al. (2010). The central nervous system as target for antihypertensive actions of a proline-rich peptide from Bothrops jararaca venom. Cytometry A 77, 220-230. doi: 10.1002/cyto.a.20860

Lameu, C., Trujillo, C. A., Schwindt, T. T., Negraes, P. D., Pillat, M. M., Morais, K. L., et al. (2012). Interactions between the NO-citrulline cycle and brain-derived neurotrophic factor in differentiation of neural stem cells. J. Biol. Chem. 287, 29690-29701. doi: 10.1074/jbc.M111.338095

Leeb-Lundberg, L. M., Song, X. H., and Mathis, S. A. (1994). Focal adhesionassociated proteins p125FAK and paxillin are substrates for bradykininstimulated tyrosine phosphorylation in swiss 3T3 cells. J. Biol. Chem. 269, 24328-24334.

Livak, K. J., and Schmittgen, T. D. (2001). Analysis of relative gene expression data using real-time quantitative PCR and the $2^{-\Delta \Delta C T}$ method. Methods 25, 402-408. doi: 10.1006/meth.2001.1262

Megison, M. L., Stewart, J. E., Nabers, H. C., Gillory, L. A., and Beierle, E. A. (2013). FAK inhibition decreases cell invasion, migration and metastasis in MYCN amplified neuroblastoma. Clin. Exp. Metastasis 30, 555-568. doi: $10.1007 /$ s10585-012-9560-7

Paget, S. (1889). The distribution of secondary growths in cancer of the breast. Lancet 133, 571-573. doi: 10.1016/S0140-6736(00)49915-0

Palacios-Moreno, J., Foltz, L., Guo, A., Stokes, M. P., Kuehn, E. D., George, L., et al. (2015). Neuroblastoma tyrosine kinase signaling networks involve FYN and LYN in endosomes and lipid rafts. PLoS Comput. Biol. 11:e1004130. doi: 10.1371/journal.pcbi.1004130

Pinheiro, A. R., Paramos-de-Carvalho, D., Certal, M., Costa, C., MagalhãesCardoso, M. T., Ferreirinha, F., et al. (2013). Bradykinin-induced Ca2+ signaling in human subcutaneous fibroblasts involves ATP release via hemichannels leading to P2Y12 receptors activation. Cell Commun. Signal. 11:70. doi: 10.1186/1478-811X-11-70

Raffaghello, L., Chiozzi, P., Falzoni, S., Di Virgilio, F., and Pistoia, V. (2006). The P2X7 receptor sustains the growth of human neuroblastoma cells through a substance P-dependent mechanism. Cancer Res. 66, 907-914. doi: 10.1158/0008-5472.CAN-05-3185

Rao, J. S. (2003). Molecular mechanisms of glioma invasiveness: the role of proteases. Nat. Rev. Cancer 3, 489-501. doi: 10.1038/nrc1121

Ratajczak, M. Z., Jadczyk, T., Schneider, G., Kakar, S. S., and Kucia, M. (2013). Induction of a tumor-metastasis-receptive microenvironment as an unwanted and underestimated side effect of treatment by chemotherapy or radiotherapy. J. Ovarian Res. 6:95. doi: 10.1186/1757-2215-6-95 
Roger, S., and Pelegrin, P. (2011). P2X7 receptor antagonism in the treatment of cancers. Expert Opin. Investig. Drugs 20, 875-880. doi: 10.1517/13543784.2011.583918

Roy, I., Getschman, A. E., Volkman, B. F., and Dwinell, M. B. (2017). Exploiting agonist biased signaling of chemokines to target cancer. Mol. Carcinog. 56, 804-813. doi: $10.1002 / \mathrm{mc} .22571$

Rundhaug, J. E. (2005). Matrix metalloproteinases and angiogenesis angiogenesis review series. J. Cell. Mol. Med. 9, 267-285. doi: 10.1111/j.1582-4934.2005.tb00355.x

Russell, H. V., Hicks, J., Okcu, M. F., and Nuchtern, J. G. (2004). CXCR4 Expression in neuroblastoma primary tumors is associated with clinical presentation of bone and bone marrow metastases. J. Pediatr. Surg. 39, 1506-1511. doi: 10.1016/j.jpedsurg.2004.06.019

Ryu, J. K., Jantaratnotai, N., Serrano-Perez, M. C., McGeer, P. L., and McLarnon, J. G. (2011). Block of purinergic P2X7R inhibits tumor growth in a c6 glioma brain tumor animal model. J. Neuropathol. Exp. Neurol. 70, 13-22. doi: 10.1097/NEN.0b013e318201d4d4

Schneider, G., Glaser, T., Lameu, C., Abdelbaset-Ismail, A., Sellers, Z. P., Moniuszko, M., et al. (2015). Extracellular nucleotides as novel, underappreciated pro-metastatic factors that stimulate purinergic signaling in human lung cancer cells. Mol. Cancer 14:201. doi: 10.1186/s12943-015-0469-Z

Seeger, R. C., Patrick Reynolds, C., Gallego, R., Stram, D. O., Gerbing, R. B., and Matthay, K. K. (2000). Quantitative tumor cell content of bone marrow and blood as a predictor of outcome in stage IV neuroblastoma: a children's cancer group study. J. Clin. Oncol. 18, 4067-4076. doi: 10.1200/JCO.2000.18.24.4067
Shafat, I., Vlodavsky, I., and Ilan, N. (2006). Characterization of mechanisms involved in secretion of active heparanase. J. Biol. Chem. 281, 23804-23811. doi: 10.1074/jbc.M602762200

Trujillo, C. A., Negraes, P. D., Schwindt, T. T., Lameu, C., Carromeu, C., Muotri, A. R., et al. (2012). Kinin-B2 receptor activity determines the differentiation fate of neural stem cells. J. Biol. Chem. 287, 44046-44061. doi: 10.1074/jbc.M112.407197

Wysoczynski, M., Miekus, K., Jankowski, K., Wanzeck, J., Bertolone, S., Janowska-Wieczorek, A., et al. (2007). Leukemia inhibitory factor: a newly identified metastatic factor in rhabdomyosarcomas. Cancer Res. 67, 2131-2140. doi: 10.1158/0008-5472.CAN06-1021

Conflict of Interest Statement: The authors declare that the research was conducted in the absence of any commercial or financial relationships that could be construed as a potential conflict of interest.

Copyright (C) 2018 Ulrich, Ratajczak, Schneider, Adinolfi, Orioli, Ferrazoli, Glaser, Corrêa-Velloso, Martins, Coutinho, Santos, Pillat, Sack and Lameu. This is an openaccess article distributed under the terms of the Creative Commons Attribution License (CC BY). The use, distribution or reproduction in other forums is permitted, provided the original author(s) and the copyright owner are credited and that the original publication in this journal is cited, in accordance with accepted academic practice. No use, distribution or reproduction is permitted which does not comply with these terms. 